\title{
Synthesis of $\mathrm{MFe}_{3} \mathrm{~S}_{4}$ Clusters Containing a Planar M"Site (M = Ni, $\mathrm{Pd}, \mathrm{Pt}$ ), a Structural Element in the C-Cluster of Carbon Monoxide Dehydrogenase
}

\author{
Rashmishree Panda, Curtis P. Berlinguette, Yugen Zhang, and Richard H. Holm \\ Department of Chemistry and Chemical Biology, Harvard University, Cambridge, Massachusetts \\ 02138
}

\begin{abstract}
Synthesis of an analogue of the C-cluster of $C$. hydrogenoformans carbon monoxide dehydrogenase requires formation of a planar $\mathrm{Ni}^{\mathrm{II}}$ site and attachment of an exo iron atom in the core unit $\mathrm{NiFe}_{4} \mathrm{~S}_{5}$. The first objective has been achieved by two reactions: (i) displacement of $\mathrm{Ph}_{3} \mathrm{P}$ or $\mathrm{Bu}^{t} \mathrm{NC}$ at tetrahedral $\mathrm{Ni}^{\mathrm{II}}$ sites of cubane-type $\left[\mathrm{NiFe}_{3} \mathrm{~S}_{4}\right]^{1+}$ clusters with chelating diphosphines, and (ii) metal atom incorporation into a cuboidal $\left[\mathrm{Fe}_{3} \mathrm{~S}_{4}\right]^{0}$ cluster with a $\mathrm{M}^{0}$ reactant in the presence of dmpe. The isolated product clusters $\left[(\mathrm{dmpe}) \mathrm{MFe}_{3} \mathrm{~S}_{4}\left(\mathrm{LS}_{3}\right)\right]^{2-}\left(\mathrm{M}=\mathrm{Ni}^{\mathrm{II}}(\mathbf{9}), \mathrm{Pd}^{\mathrm{II}}(\mathbf{1 2}), \mathrm{Pt}^{\mathrm{II}}(\mathbf{1 3})\right)$ contain the cores $\left[\mathrm{MFe}_{3}\left(\mu_{2}-\mathrm{S}^{*}\right)\left(\mu_{3}-\mathrm{S}\right)_{3}\right]^{1-}$ having planar $\mathrm{M}^{\mathrm{II}} \mathrm{P}_{2} \mathrm{~S}_{2}$ sites and variable non-bonding $\mathrm{M} \cdots \mathrm{S}^{*}$ distances of 2.6-3.4 A. Reaction (i) involves a tetrahedral $\rightarrow$ planar $\mathrm{Ni}^{\mathrm{II}}$ structural change between isomeric cubane and cubanoid $\left[\mathrm{NiFe}_{3} \mathrm{~S}_{4}\right]^{1+}$ cores. Based on the magnetic properties of $\mathbf{1 2}$ and earlier considerations, the $\mathrm{S}=5 / 2$ ground state of the cubanoid cluster arises from the $\left[\mathrm{Fe}_{3} \mathrm{~S}_{4}\right]^{1-}$ fragment, whereas the $\mathrm{S}=3 / 2$ ground state of the cubane cluster is a consequence of antiferromagnetic coupling between the spins of $\mathrm{Ni}^{2+}(\mathrm{S}=1)$ and $\left[\mathrm{Fe}_{3} \mathrm{~S}_{4}\right]^{1-}$. Other substitution reactions of $\left[\mathrm{NiFe}_{3} \mathrm{~S}_{4}\right]^{1+}$ clusters and 1:3 site-differentiated $\left[\mathrm{Fe}_{4} \mathrm{~S}_{4}\right]^{2+}$ clusters are described, as are the structures of 12, 13, $\left[\left(\mathrm{Me}_{3} \mathrm{P}\right)\right.$ $\left.\mathrm{NiFe}_{3} \mathrm{~S}_{4}\left(\mathrm{LS}_{3}\right)\right]^{2-}$, and $\left[\mathrm{Fe}_{4} \mathrm{~S}_{4}\left(\mathrm{LS}_{3}\right) \mathrm{L}^{\prime}\right]^{2-}\left(\mathrm{L}^{\prime}=\mathrm{Me}_{2} \mathrm{NC}_{2} \mathrm{H}_{4} \mathrm{~S}^{-}, \mathrm{Ph}_{2} \mathrm{P}(\mathrm{O}) \mathrm{C}_{2} \mathrm{H}_{4} \mathrm{~S}^{-}\right)$. This work significantly expands our initial report of cluster 9 (Panda et al., J. Am. Chem. Soc. 2004, 126, 64486459 ) and further demonstrates that a planar $\mathrm{M}^{\mathrm{II}}$ site can be stabilized within a cubanoid $\left[\mathrm{NiFe}_{3} \mathrm{~S}_{4}\right]^{1+}$ core. $(\mathrm{dmpe}=$ bis(1,2-dimethylphosphino)ethane; 1,3,5-tris((4,6-dimethyl-3mercaptophenyl)thio)-2,4,6-tris( $p$-tolylthio)benzene(3-)).
\end{abstract}

\section{Introduction}

All carbon monoxide dehydrogenases catalyze the reaction $\mathrm{CO}+\mathrm{H}_{2} \mathrm{O} \rightleftharpoons \mathrm{CO}_{2}+2 \mathrm{H}^{+}+2 \mathrm{e}^{-}$. Bifunctional enzymes also catalyze the formation of acetylcoenzyme $\mathrm{A}$ from carbon monoxide, a methyl group supplied by a corrinoid protein, and coenzyme A. ${ }^{1-3}$ The acetylcoenzyme A synthase activity occurs at the A-cluster, a bridged assembly with minimal formulation $\left[\mathrm{Fe}_{4} \mathrm{~S}_{4}\right]-\left(\mu_{2}-\mathrm{S}_{\mathrm{Cys}}\right)-\left[\mathrm{Ni}\left(\left(\mu_{2}-\mathrm{S}_{\mathrm{Cys}}\right)_{2} \mathrm{Gly}\right) \mathrm{Ni}\right]$ whose structure has been revealed by protein crystallography 4,5 and di-nickel content has been shown to be essential for activity. ${ }^{5-7}$ The $\mathrm{CO} / \mathrm{CO}_{2}$ interconversion reaction occurs at the $\mathrm{C}$-cluster, a complicated $\mathrm{Ni}-\mathrm{Fe}-\mathrm{S}$ cluster with a cubanoid geometry which is of principal interest in this work. Both clusters represent substantial challenges in the synthesis of weak-field heterometal clusters that are analogues of native clusters in biology. 8

Shown in Figure 1 are $\mathrm{X}$-ray structures of three $\mathrm{C}$-clusters from different organisms. All contain a $\mathrm{NiFe}_{4}\left(\mu_{3}-\mathrm{S}\right)_{4}$ core with distorted tetrahedral iron sites, among which is an iron atom with 
apparent $\mathrm{Fe}\left(\mu_{2}-\mathrm{S}\right)\left(\mu_{3}-\mathrm{S}\right)\left(\mathrm{S}_{\mathrm{Cys}}\right)\left(\mathrm{N}_{\mathrm{His}}\right)$ coordination that is positioned exo to the cubanoid $\mathrm{NiFe}_{3} \mathrm{~S}_{4}$ portion of the core. The structures differ mainly in the coordination around nickel. The dithionite-reduced cluster of $C h$ CODH II, ${ }^{9}$ recently reported at $1.12 \AA$ resolution ${ }^{10}$ after an initial determination at $1.63 \AA,{ }^{11}$ is the most accurately determined structure. This cluster features planar $\mathrm{NiS}_{4}$ coordination, and a tetrahedral exo iron atom connected to the $\mathrm{NiFe}_{3} \mathrm{~S}_{4}$ portion by one $\mu_{2}-\mathrm{S}$ and one $\mu_{3}-\mathrm{S}^{*}$ bridge. Two structures of the $M t \mathrm{CODH}$ cluster include the exo iron atom but lack the $\mu_{2}$-S bridge interaction. ${ }^{4,5}$ The $1.9 \AA$ structure has been modeled with a CO ligand and distorted tetrahedral coordination at the nickel site. ${ }^{5}$ The C-cluster of $R r$ is interpreted in terms of a $\mu_{2}-\mathrm{S}_{\mathrm{Cys}}$ bridge and carries an unidentified ligand at the nickel site. Several of these structures exhibit partial atom occupancies and disordered positions. Further, evidence exists that treatment with $\mathrm{CO}$ causes structural changes and may be responsible for the absence of the $\mu_{2}-\mathrm{S}$ bridge in the $M t$ and $\operatorname{Rr}$ C-cluster structures. ${ }^{10,12}$ Nonetheless, certain constant core structural features have emerged that serve as a basis for synthetic approaches to the $\mathrm{C}$-cluster.

We proceed on the basis that the C-cluster of $\mathrm{Ch} \mathrm{CODH}$ II is the best current definition of the biological structure. Dobbek et al. ${ }^{10}$ conclude that the $\mu_{2}$-S bridge is necessary for activity; hence, the depicted cluster is functional. We note the dissenting interpretation of Feng and Lindahl ${ }^{13}$ which, however, is difficult at present to translate into a definite structural objective. The results of nickel K-edge X-ray absorption spectroscopy of the cluster are consistent with a $\mathrm{Ni}^{\mathrm{II}} \mathrm{S}_{4}$ coordination unit and a bond distance of $2.20 \AA .{ }^{2}$ The cluster structures depicted in Figure 1 are designated as cubanoid rather than cubane-type because the axial $\mathrm{Ni} \cdots \mathrm{S}^{*}$ separation in each is much longer than the 2.2-2.3 $\AA$ distances found in authentic $\mathrm{NiFe}_{3} \mathrm{~S}_{4}$ cubanes containing tetrahedral $\mathrm{Ni}^{\mathrm{II}}$. ${ }^{4}, 15$ In planar complexes, $\mathrm{Ni}^{\mathrm{II}}$-S bond lengths to anionic ligands fall in the 2.10-2.25 $\AA$ range. Cubane-type clusters are potential precursors to the $\mathrm{C}$ cluster structure. Achievement of that structure may be formulated in two steps: (i) creation of a planar $\mathrm{Ni}^{\mathrm{II}}$ site within the $\mathrm{NiFe}_{3} \mathrm{~S}_{4}$ core; (ii) introduction of a tetrahedral $\mathrm{F}_{\mathrm{e}} \mathrm{II}, \mathrm{III}$ site with bridges exo to the core in (i) to generate, ideally, the complete $\mathrm{NiFe}_{4} \mathrm{~S}_{5}$ core.

In initial experiments directed at step (i), we demonstrated the occurrence of reaction I. ${ }^{16}$ Here a $\mathrm{NiFe}_{3} \mathrm{~S}_{4}$ cubane-type cluster supported by the semirigid trithiolate ligand $\mathrm{LS}_{3}{ }^{17}$ reacts with a chelating diphosphine in a ligand substitution process resulting in the conversion from a tetrahedral paramagnetic $\mathrm{Ni}^{\mathrm{II}} \mathrm{PS}_{3}$ to a planar diamagnetic $\mathrm{Ni}^{\mathrm{II}} \mathrm{P}_{2} \mathrm{~S}_{2}$ configuration. In the process, the $\left[\mathrm{NiFe}_{3} \mathrm{~S}_{4}\right]^{1+}$ core changes from a $\mathrm{S}=3 / 2$ to a $\mathrm{S}=5 / 2$ ground state. The $\mathrm{NiFe}_{3} \mathrm{~S}_{4}$ portion of the product cluster is cubanoid inasmuch as the axial $\mathrm{Ni} \cdots \mathrm{S}^{*}$ separations in independent clusters are 2.60-2.90 ̊. ${ }^{16}$

$\left[\left(\mathrm{Ph}_{3} \mathrm{P}\right) \mathrm{NiFe}_{3} \mathrm{~S}_{4}\left(\mathrm{LS}_{3}\right)\right]^{2-}+\mathrm{dmpe} \rightarrow\left[(\mathrm{dmpe}) \mathrm{NiFe}_{3} \mathrm{~S}_{4}\left(\mathrm{LS}_{3}\right)\right]^{2-}+\mathrm{Ph}_{3} \mathrm{P}$

While the product cluster of reaction 1 lacks the exo iron atom and contains a non-physiological ligand, it resembles a C-cluster by the integration of planar $\mathrm{Ni}^{\mathrm{II}}$, with an accompanying long $\mathrm{Ni} \cdots \mathrm{S}^{*}$ distance, into a $\mathrm{NiFe}_{3} \mathrm{~S}_{4}$ unit. This unit, with planar $\mathrm{Ni}^{\mathrm{II}}$ in the best defined case, is a constant structural component of C-clusters. The present investigation and that preceding it ${ }^{16}$ disclose our current approach to C-cluster synthetic analogues. In this work, we address more generally the ligand substitution chemistry of tetrahedral $\mathrm{Ni}^{\mathrm{II}}$ in a cubane-type cluster, provide other reactions leading to the formation of planar sites in cubanoid clusters, and document certain substitution reactions of cubane-type $\mathrm{Fe}_{4} \mathrm{~S}_{4}$ clusters. Related research in this laboratory is directed toward the attainment of analogues of the A-cluster of bifunctional CODH. ${ }^{18,19}$ 


\section{Experimental Section}

\section{Preparation of Compounds}

All reactions and manipulations were performed under a pure dinitrogen atmosphere using either Schlenk techniques or an inert atmosphere box. Solvents were passed through an Innovative Technology solvent purification system prior to use. Volume reduction and drying steps were carried out in vacuo. Because of the small scale of the preparations, compounds were not analyzed. Those in Table 1 were characterized by X-ray structure determinations. In addition, all clusters display sharp, isotropically shifted ${ }^{1} \mathrm{H}$ NMR spectra. In conjunction with an extensive data set for complexes of the types $\left[\mathrm{L}^{\prime} \mathrm{NiFe}_{3} \mathrm{~S}_{4}\left(\mathrm{LS}_{3}\right)\right]^{\mathrm{z}} 16,17$ and $\left[\mathrm{Fe}_{4} \mathrm{~S}_{4}\left(\mathrm{LS}_{3}\right) \mathrm{L}\right.$ ' $\mathrm{j}^{\mathrm{z} 20-24}$ obtained in this laboratory, the spectra allow detection of reaction products and establishment of the identity and satisfactory purity of isolated compounds. Selected clusters 12, 13, and 16 were also verified by electrospray mass spectrometry. Spectra of species corresponding to $\left\{\mathrm{M}^{2-}+\mathrm{H}^{+}\right\}^{1-}$ displayed isotope patterns in excellent agreement with calculated values.

\section{$\left(\mathrm{Et}_{4} \mathrm{~N}\right)_{2}\left[\left(\mathrm{Bu}^{t} \mathrm{NC}\right) \mathrm{NiFe}_{3} \mathrm{~S}_{4}\left(\mathrm{LS}_{3}\right)\right]\left(\left(\mathrm{Et}_{4} \mathrm{~N}\right)_{2}[2]\right)$}

To a solution of $\left(\mathrm{Et}_{4} \mathrm{~N}\right)_{3}\left[\mathrm{Fe}_{3} \mathrm{~S}_{4}\left(\mathrm{LS}_{3}\right)\right]^{25}(100 \mathrm{mg}, 61.2 \mu \mathrm{mol})$ in $25 \mathrm{~mL}$ of acetonitrile was added a solution of $\left[\mathrm{Ni}\left(\mathrm{CNBu}^{\dagger}\right)_{4}\right]^{26}(28.7 \mathrm{mg}, 73.4 \mu \mathrm{mol})$ in $5 \mathrm{~mL}$ of acetonitrile. The solution was stirred for $2 \mathrm{~h}$, and the solvent was removed to leave a dark brown solid. The solid was washed with ether $(5 \mathrm{~mL})$ and dried to afford the product as $94 \mathrm{mg}(93 \%)$ of a brown solid. ${ }^{1} \mathrm{H}$ NMR $\left(\mathrm{CD}_{3} \mathrm{CN}\right.$, anion): $\delta$ 14.34 (5-H); 12.04,8.81 (6-Me, 4-Me); 7.46, 6.25 (2'-H, '$\mathrm{H}) ; 2.30$ ('-Me), $0.88\left(\mathrm{Bu}^{t}\right)$.

\section{$\left(\mathrm{Et}_{4} \mathrm{~N}\right)_{2}\left[\left(\mathrm{Me}_{3} \mathrm{P}\right) \mathrm{NiFe}_{3} \mathrm{~S}_{4}\left(\mathrm{LS}_{3}\right)\left(\left(\mathrm{Et}_{4} \mathrm{~N}\right)_{2}[3]\right)\right.$}

To a solution of $\left(\mathrm{Et}_{4} \mathrm{~N}\right)_{2}\left[\left(\mathrm{Bu}^{t} \mathrm{NC}\right) \mathrm{NiFe}_{3} \mathrm{~S}_{4}\left(\mathrm{LS}_{3}\right)\right](25.0 \mathrm{mg}, 15.2 \mu \mathrm{mol})$ in $4 \mathrm{~mL}$ of acetonitrile was added $18.2 \mu \mathrm{L}$ of a $1 \mathrm{M}$ solution of $\mathrm{Me}_{3} \mathrm{P}$ in toluene. The solution was stirred for $1 \mathrm{~h}$ and filtered through Celite. Slow diffusion of ether into the filtrate gave the product as $13 \mathrm{mg}(54 \%)$ of a black crystalline solid. ${ }^{1} \mathrm{H}$ NMR $\left(\mathrm{CD}_{3} \mathrm{CN}\right.$, anion): $\delta 39.6\left(\mathrm{Me}_{3} \mathrm{P}\right), 14.38(5-\mathrm{H}) ; 11.76,8.59$ (6-Me, 4-Me); 7.39, 6.21 (2'-H, 3'-H); 2.28 (4'-Me).

\section{$\left(\mathrm{Et}_{4} \mathrm{~N}\right)_{2}\left[(\mathrm{dmpe}) \mathrm{NiFe}_{3} \mathrm{~S}_{4}\left(\mathrm{LS}_{3}\right)\right]\left(\left(\mathrm{Et}_{4} \mathrm{~N}\right)_{2}[9]\right)$}

To a solution of $\left(\mathrm{Et}_{4} \mathrm{~N}\right)_{3}\left[\mathrm{Fe}_{3} \mathrm{~S}_{4}\left(\mathrm{LS}_{3}\right)\right](100 \mathrm{mg}, 61.2 \mu \mathrm{mol})$ in $16 \mathrm{~mL}$ of acetonitrile was added a suspension of $\left[\mathrm{Ni}(\mathrm{cod})_{2}\right](18.5 \mathrm{mg}, 67.3 \mu \mathrm{mol})$ in $4 \mathrm{~mL}$ of DMF, followed by the addition of dmpe $(11.2 \mu \mathrm{L}, 67.3 \mu \mathrm{mol})$. The reaction mixture was stirred for $4 \mathrm{~h}$, filtered, and the filtrate was taken to dryness in vacuo. The black solid was washed with ether $(3 \times 5 \mathrm{~mL})$, and dried in vacuo. This material was recrystallized from acetonitrile/DMF $(5: 1 \mathrm{v} / \mathrm{v})$ by means of vapor diffusion of ether to afford the product as $45 \mathrm{mg}(43 \%)$ of black needles. The ${ }^{\mathrm{I}} \mathrm{H}$ NMR spectrum of this material is identical to that of authentic $\left[(\mathrm{dmpe}) \mathrm{NiFe}_{3} \mathrm{~S}_{4}\left(\mathrm{LS}_{3}\right)\right]^{2-}$ prepared by a different method. ${ }^{16}$

\section{$\left(\mathrm{Et}_{4} \mathrm{~N}\right)_{2}\left[(\mathrm{dmpe}) \mathrm{PdFe}_{3} \mathrm{~S}_{4}\left(\mathrm{LS}_{3}\right)\right]\left(\left(\mathrm{Et}_{4} \mathrm{~N}\right)_{2}[12]\right)$}

To a solution of $\left(\mathrm{Et}_{4} \mathrm{~N}\right)_{3}\left[\mathrm{Fe}_{3} \mathrm{~S}_{4}\left(\mathrm{LS}_{3}\right)\right](100 \mathrm{mg}, 61.2 \mu \mathrm{mol})$ in $18 \mathrm{~mL}$ of acetonitrile was added a suspension of $\left[\mathrm{Pd}(\mathrm{dba})_{2}\right](42.2 \mathrm{mg}, 73.4 \mu \mathrm{mol})$ in $1.5 \mathrm{~mL}$ of $\mathrm{Me}_{2} \mathrm{SO}$ followed by the addition of dmpe $(12.3 \mu \mathrm{L}, 73.4 \mu \mathrm{mol})$. The reaction mixture was stirred for $3 \mathrm{~h}$ and filtered. Vapor diffusion of ether into the filtrate afforded the pure product as $74.0 \mathrm{mg}(69 \%)$ of black needles. Mass spectrum: $m / z 1500.0$ (calcd. for $\left.\left\{\mathrm{M}^{2-}+\mathrm{H}^{+}\right\}{ }^{1-}, 1499.9\right) .{ }^{1} \mathrm{H}$ NMR $\left(\mathrm{CD}_{3} \mathrm{CN}\right.$, anion): $\delta$ 19.32 (5-H), 17.01,13.62 (6-Me, 4-Me); 7.29, 6.49 (2'-H, 3'-H); 2.32 (4'-Me), $1.40\left(\mathrm{CH}_{2^{-}}\right.$ dmpe), 0.92 (Me-dmpe). 


\section{$\left(\mathrm{Et}_{4} \mathrm{~N}\right)_{2}\left[(\mathrm{dmpe}) \mathrm{PtFe}_{3} \mathrm{~S}_{4}\left(\mathrm{LS}_{3}\right)\right]\left(\left(\mathrm{Et}_{4} \mathrm{~N}\right)_{2}[13]\right)$}

To a solution of $\left(\mathrm{Et}_{4} \mathrm{~N}\right)_{3}\left[\mathrm{Fe}_{3} \mathrm{~S}_{4}\left(\mathrm{LS}_{3}\right)\right](50 \mathrm{mg}, 30.6 \mu \mathrm{mol})$ in $8 \mathrm{~mL}$ of acetonitrile was added a suspension of $\left[\mathrm{Pt}\left(\mathrm{PPh}_{3}\right)_{4}\right](41.0 \mathrm{mg}, 33.0 \mu \mathrm{mol})$ in $1.5 \mathrm{~mL}$ of DMF followed by the addition of dmpe $(5.5 \mu \mathrm{L}, 33.0 \mu \mathrm{mol})$. The reaction mixture was stirred for $3 \mathrm{~h}$ and filtered. Vapor diffusion of ether into the filtrate afforded the pure product as $21.0 \mathrm{mg}(38 \%)$ of black needles. Mass spectrum: $m / z 1587.4$ (calcd. for $\left.\left\{\mathrm{M}^{2-}+\mathrm{H}^{+}\right\}^{1-}, 1587.8\right)$. ${ }^{\mathrm{I}} \mathrm{H} \mathrm{NMR}\left(\mathrm{CD}_{3} \mathrm{CN}\right.$, anion): $\delta$ 16.97 (5-H), 16.25,13.40 (6-Me, 4-Me); 7.34,6.59 (2'-H, 3'-H); 2.35 (4'-Me), $2.27\left(\mathrm{CH}_{2}\right.$-dmpe), 0.03 (Me-dmpe).

\section{$\left(\mathrm{Et}_{4} \mathrm{~N}\right)_{2}\left[\mathrm{Fe}_{4} \mathrm{~S}_{4}\left(\mathrm{LS}_{3}\right)\left(\mathrm{SCH}_{2} \mathrm{CH}_{2} \mathrm{PPh}_{2}\right)\right]\left(\left(\mathrm{Et}_{4} \mathrm{~N}\right)_{2}[15]\right)$}

To a solution of $\left(\mathrm{Bu}_{4} \mathrm{~N}\right)_{2}\left[\mathrm{Fe}_{4} \mathrm{~S}_{4}\left(\mathrm{LS}_{3}\right) \mathrm{Cl}\right]^{22}(136 \mathrm{mg}, 75.0 \mu \mathrm{mol})$ in $20 \mathrm{~mL}$ of acetonitrile was added a suspension of $\mathrm{NaSCH}_{2} \mathrm{CH}_{2} \mathrm{PPh}_{2}{ }^{27}(20 \mathrm{mg}, 75.0 \mu \mathrm{mol})$ in $5 \mathrm{~mL}$ of acetonitrile. The mixture was stirred for $2 \mathrm{~h}$ and filtered into a solution of $\left(\mathrm{Et}_{4} \mathrm{~N}\right)\left(\mathrm{PF}_{6}\right)(42.0 \mathrm{~g}, 15.0 \mu \mathrm{mol})$, and that mixture was stirred for $30 \mathrm{~min}$. Ether was layered onto the solution at $-20^{\circ} \mathrm{C}$, causing separation of the product as $102 \mathrm{mg}(76 \%)$ of a dark brown solid. ${ }^{1} \mathrm{HNMR}\left(\mathrm{CD}_{3} \mathrm{CN}\right.$, anion): $812.05\left(\mathrm{SCH}_{2}\right), 8.16(5-\mathrm{H}) ; 7.96,7.85,7.53(\mathrm{Ph}) ; 7.14,6.84$ (2'-H, 3'-H); 5.10 (br, 2-H); 3.83, 3.73 (6-Me, 4-Me); $2.24\left(4^{\prime}-\mathrm{H}\right), 2.10\left(\mathrm{CH}_{2} \mathrm{P}\right)$. Mössbauer spectrum $(4.2 \mathrm{~K}): \delta=0.44 \mathrm{~mm} / \mathrm{s}$, $\Delta \mathrm{E}_{\mathrm{Q}}=1.14 \mathrm{~mm} / \mathrm{s} . \mathrm{E}_{1 / 2}=-0.47 \mathrm{~V}(1-/ 2-),-1.11 \mathrm{~V}(2-/ 3-)$ (acetonitrile).

\section{$\left(\mathrm{Bu}_{4} \mathrm{~N}\right)_{2}\left[\mathrm{Fe}_{4} \mathrm{~S}_{4}\left(\mathrm{LS}_{3}\right)\left(\mathrm{SCH}_{2} \mathrm{CH}_{2} \mathrm{PPh}_{2}\right)\right]\left(\left(\mathrm{Bu}_{4} \mathrm{~N}\right)_{2}[15]\right)$}

To a solution of $\left(\mathrm{Bu}_{4} \mathrm{~N}\right)_{2}\left[\mathrm{Fe}_{4} \mathrm{~S}_{4}\left(\mathrm{LS}_{3}\right) \mathrm{Cl}\right](400 \mathrm{mg}, 0.220 \mathrm{mmol})$ in $80 \mathrm{~mL}$ of acetonitrile was added a suspension of $\mathrm{NaSCH}_{2} \mathrm{CH}_{2} \mathrm{PPh}_{2}(59 \mathrm{mg}, 0.22 \mathrm{mmol})$ in $10 \mathrm{~mL}$ of acetonitrile. The mixture was stirred for $2 \mathrm{~h}$, filtered through Celite, and the solvent was removed in vacuo. The product was obtained as $0.365 \mathrm{~g}(82 \%)$ of a glassy black solid. The ${ }^{1} \mathrm{H}$ NMR spectrum of the anion was identical to that of the preceding preparation. Mössbauer spectrum $(4.2 \mathrm{~K}): \delta=0.45$ $\mathrm{mm} / \mathrm{s}, \Delta \mathrm{E}_{\mathrm{Q}}=1.14 \mathrm{~mm} / \mathrm{s}$.

\section{$\left(\mathrm{Et}_{4} \mathrm{~N}\right)_{2}\left[\mathrm{Fe}_{4} \mathrm{~S}_{4}\left(\mathrm{LS}_{3}\right)\left(\mathrm{SCH}_{2} \mathrm{CH}_{2} \mathrm{NMe}_{2}\right)\right]\left(\left(\mathrm{Et}_{4} \mathrm{~N}\right)_{2}[16]\right)$}

To a solution of $\left(\mathrm{Bu}_{4} \mathrm{~N}\right)_{2}\left[\mathrm{Fe}_{4} \mathrm{~S}_{4}\left(\mathrm{LS}_{3}\right) \mathrm{Cl}\right](52 \mathrm{mg}, 29 \mu \mathrm{mol})$ in $10 \mathrm{~mL}$ of acetonitrile was added a suspension of $\mathrm{NaSCH}_{2} \mathrm{CH}_{2} \mathrm{NMe}_{2}(3.6 \mathrm{mg}$. $29 \mu \mathrm{mol})$ in $5 \mathrm{~mL}$ of acetonitrile. The mixture was stirred for $2 \mathrm{~h}$ and filtered into a solution of $\left(\mathrm{Et}_{4} \mathrm{~N}\right)\left(\mathrm{PF}_{6}\right)(16 \mathrm{mg}, 57 \mu \mathrm{mol})$, and that mixture was stirred for $30 \mathrm{~min}$. Ether was layered onto the solution at $-20^{\circ} \mathrm{C}$, causing separation of the product as $37 \mathrm{mg}(80 \%)$ of a dark brown solid. Mass spectrum: $\mathrm{m} / \mathrm{z} 1402.9$ (calcd. for $\left.\left\{\mathrm{M}^{2-}+\mathrm{H}^{+}\right\}^{1-}, 1402.8\right)$. Mössbauer spectrum $(4.2 \mathrm{~K}): \delta=0.45 \mathrm{~mm} / \mathrm{s}, \Delta \mathrm{E}_{\mathrm{Q}}=1.14 \mathrm{~mm} / \mathrm{s} .{ }^{1} \mathrm{H}$ NMR $\left(\mathrm{CD}_{3} \mathrm{CN}\right.$, anion): $\delta 20.90\left(\mathrm{SCH}_{2}\right), 8.23(5-\mathrm{H}), 7.15,6.76\left(2^{\prime}-\mathrm{H}, 3^{\prime}-\mathrm{H}\right) ; 6.85\left(\mathrm{NMe}_{2}\right), 5.00$ (2-H), 3.89, $3.64(6-\mathrm{Me}, 4-\mathrm{Me}) ; 2.26\left(4^{\prime}-\mathrm{Me}\right), 2.12\left(\mathrm{CH}_{2} \mathrm{~N}\right) . \mathrm{E}_{1 / 2}=-0.16 \mathrm{~V}(1-/ 2-),-1.14 \mathrm{~V}$ (acetonitrile).

\section{$\left(\mathrm{Bu}_{4} \mathrm{~N}\right)_{2}\left[\mathrm{Fe}_{4} \mathrm{~S}_{4}\left(\mathrm{LS}_{3}\right)\left(\mathrm{SCH}_{2} \mathrm{CH}_{2} \mathrm{NMe}_{2}\right)\right]\left(\left(\mathrm{Bu}_{4} \mathrm{~N}\right)_{2}[16]\right.$}

To a solution of $\left(\mathrm{Bu}_{4} \mathrm{~N}\right)_{2}\left[\mathrm{Fe}_{4} \mathrm{~S}_{4}\left(\mathrm{LS}_{3}\right) \mathrm{Cl}\right](200 \mathrm{mg}, 0.110 \mathrm{mmol})$ in $40 \mathrm{~mL}$ of acetonitrile was added a suspension of $\mathrm{NaSCH}_{2} \mathrm{CH}_{2} \mathrm{NMe}_{2}(14 \mathrm{mg}, 0.11 \mathrm{mmol})$ in $5 \mathrm{~mL}$ of acetonitrile. The mixture was stirred for $3 \mathrm{~h}$, filtered through Celite, and the solvent was removed in vacuo. The black solid was dissolved in $20 \mathrm{~mL}$ of acetonitrile, the solution was filtered, and the filtrate was layered with ether. The solid which separated was washed with ether and dried in vacuo to afford the product as $160 \mathrm{mg}$ (77\%) of a glassy black solid. Mössbauer spectrum (4.2 K): $\delta=0.45 \mathrm{~mm} / \mathrm{s}, \Delta \mathrm{E}_{\mathrm{Q}}=1.13 \mathrm{~mm} / \mathrm{s}$. Mass spectrum: $m / z 1402.6\left(\left\{\mathrm{M}^{2-}+\mathrm{H}^{+}\right\}^{1-}\right)$. The ${ }^{1} \mathrm{H}$ NMR spectrum of the anion was identical to that of the preceding preparation. 


\section{Generation of Clusters in Solution}

A series of clusters of the type $\left[\mathrm{L}^{\prime} \mathrm{NiFe}_{3} \mathrm{~S}_{4}\left(\mathrm{LS}_{3}\right)\right]^{2-, 3-}$ were prepared in situ by the substitution reactions of $\left[\left(\mathrm{Bu}^{t} \mathrm{NC}\right) \mathrm{NiFe}_{3} \mathrm{~S}_{4}\left(\mathrm{LS}_{3}\right)\right]^{2-}$ summarized in Figure 2. In a typical experiment, a known amount of reactant (1.0-1.1 equiv) as a solution or suspension in $\mathrm{CD}_{3} \mathrm{CN}$ was added to a $c a .10 \mathrm{mM}$ solution of starting cluster in $\mathrm{CD}_{3} \mathrm{CN}$. Product identity was established by ${ }^{1} \mathrm{H}$ NMR spectroscopy. The compounds bicyclo[2.2.1] hepta-exo-cis-2,3-dithiol, ${ }^{28}$ $\mathrm{Ph}_{2} \mathrm{PCH}_{2} \mathrm{CH}_{2} \mathrm{SH},{ }^{27}\left(\mathrm{Et}_{4} \mathrm{~N}\right)_{2}\left[\left(\mathrm{Ph}_{3} \mathrm{P}\right) \mathrm{NiFe}_{3} \mathrm{~S}_{4}\left(\mathrm{LS}_{3}\right)\right],{ }^{17}\left[\mathrm{Ni}\left(\mathrm{PPh}_{3}\right)_{2}\left(\mathrm{Bu}^{t} \mathrm{NC}\right)_{2}\right],{ }^{29}\left[\mathrm{Ni}^{2}\left(\mathrm{PMe}_{3}\right)_{4}\right]$, $26\left(\mathrm{Et}_{4} \mathrm{~N}\right)_{2}\left[\mathrm{Fe}(\mathrm{SEt})_{4}\right],{ }^{30}\left[\mathrm{Ni}\left(\mathrm{PPh}_{3}\right)_{2}(\mathrm{mnt})\right],{ }^{31}\left(\mathrm{Et}_{4} \mathrm{~N}\right)\left[\mathrm{MCl}_{4}\right](\mathrm{M}=\mathrm{Fe}, \mathrm{Co}, \mathrm{Ni}),{ }^{32}$ and $[\mathrm{Ni}$ $\left.(\mathrm{SPh})_{2}\left(\mathrm{PEt}_{3}\right)_{2}\right]^{33}$ were prepared as described. Other compounds were commercial samples. Similar experiments were conducted in acetonitrile with $\left[\left(\mathrm{Ph}_{3} \mathrm{P}\right) \mathrm{NiFe}_{3} \mathrm{~S}_{4}\left(\mathrm{LS}_{3}\right)\right]^{2-}$ or $\left[\left(\mathrm{Bu}^{t} \mathrm{NC}\right)\right.$ $\left.\mathrm{NiFe}_{3} \mathrm{~S}_{4}\left(\mathrm{LS}_{3}\right)\right]^{2-}$ and the sodium salts of $\mathrm{Ph}_{2} \mathrm{PCH}_{2} \mathrm{CH}_{2} \mathrm{SH}, \mathrm{Me}_{2} \mathrm{PCH}_{2} \mathrm{CH}_{2} \mathrm{SH},{ }_{1,2-}$ $\mathrm{Ph}_{2} \mathrm{PC}_{6} \mathrm{H}_{4} \mathrm{SH},{ }^{35}$ and $\mathrm{Me}_{2} \mathrm{NCH}_{2} \mathrm{CH}_{2} \mathrm{SH}$ (see text).

In the following sections, clusters are designated numerically as in the Chart.

\section{X-ray Structure Determinations}

The structures of the five compounds listed in Table 1 were determined. Suitable crystals were obtained by ether diffusion $\left(\left(\mathrm{Et}_{4} \mathrm{~N}\right)_{2}[\mathbf{3}] \cdot 1 / 2 \mathrm{MeCN},\left(\mathrm{Et}_{4} \mathrm{~N}\right)_{2}[\mathbf{1 2}] \cdot 1.25 \mathrm{MeCN} \cdot 0.25 \mathrm{Et}_{2} \mathrm{O}\right.$, $\left.\left(\mathrm{Et}_{4} \mathrm{~N}\right)_{2}[13] \cdot 1.5 \mathrm{MeCN}\right)$ and hexane diffusion $\left(\left(\mathrm{Et}_{4} \mathrm{~N}\right)_{2}[\mathbf{1 6}] \cdot 2 \mathrm{MeCN}\right)$ into acetonitrile solutions. The phosphine oxide compound $\left(\mathrm{Et}_{4} \mathrm{~N}\right)_{2}[17] \cdot 1 / 2 \mathrm{MeCN}$ was formed during the attempted crystallization of 15 from acetonitrile. Data for crystals containing 3,16, and 17 were collected on a Siemens (Bruker) SMART CCD-based diffractometer. Data for crystals containing 12 and 13 were obtained with a Siemens (Bruker) APEX CCD diffractometer. Cell parameters were retrieved using SMART software and refined with SAINT on all observed reflections. Data were collected using $0.3^{\circ}$ intervals in $\phi$ and $\omega$ for $30 \mathrm{~s} /$ frame such that a hemisphere of data was collected. A total of 1270 frames was collected with a maximum resolution of 0.75 $\AA$. The first 50 frames were recollected as the end of the data collection to monitor for decay; none was found. The highly redundant data sets were reduced using SAINT and corrected for Lorentz and polarization effects. Absorption corrections were applied with SADABS.

Structures were solved by direct methods using SHELXL-97. The positions of the metal atoms and coordinated atoms were located from direct-methods E-maps; other non-hydrogen atoms were found in alternating difference Fourier syntheses and least-squares refinement cycles. These atoms were refined anisotropically during the final cycles. Hydrogen atoms were placed in calculated positions and refined as riding atoms with a uniform value of $U_{\text {iso. }}$. Crystallographic data are collected in Table $1 .^{37}$

\section{Other Physical Measurements}

${ }^{1} \mathrm{H}$ NMR spectra were obtained with a Bruker AM-400 spectrometer. Electrochemical measurements were carried out with a PAR Model 263 potentiostat/galvanostat using a Pt working electrode and $0.1 \mathrm{M}\left(\mathrm{Bu}_{4} \mathrm{~N}\right)\left(\mathrm{ClO}_{4}\right)$ supporting electrolyte; potentials are referred to the SCE. Electrospray ionization mass spectra were recorded on a LCT mass spectrometer. Mössbauer spectra were collected with a constant acceleration spectrometer. Data were analyzed using WMOSS software (Web Research Inc., Edina, MN); isomer shifts are referenced to iron metal at room temperature. Magnetic measurements were made with a Quantum Design MPMS-XL SQUID magnetometer (Texas A\&M University).

\section{Results and Discussion}

The closest synthetic approach to the C-clusters are $\mathrm{NiFe}_{3}\left(\mu_{3}-\mathrm{S}_{4}\right)$ cubane-type clusters with tetrahedral metal sites; methods of synthesis have been summarized. ${ }^{16}$ All isolated clusters of this type contain the $\left[\mathrm{NiFe}_{3} \mathrm{~S}_{4}\right]^{1+}$ core. The oxidation states $\left[\mathrm{NiFe}_{3} \mathrm{~S}_{4}\right]^{2+, 0}$ have been detected electrochemically but not isolated. ${ }^{14,15,17}$ 


\section{Synthesis and Reactions of $\mathrm{NiFe}_{3} \mathrm{~S}_{4}$ Cubane-Type Clusters}

Relevant reactions are summarized in Figure 2. In certain cases (5,7-9), clusters were isolated in this or past work; in all other reactions, cluster formation in situ was detected by isotropically shifted ${ }^{1} \mathrm{H}$ NMR spectra characteristic of the core oxidation state.

(a) Reactions based on Cuboidal Cluster 1-The synthetic procedure utilized here for $\mathrm{NiFe}_{3} \mathrm{~S}_{4}$ clusters with tetrahedral $\mathrm{Ni}^{\mathrm{II}}$ sites is metal incorporation into the cuboidal $\left[\mathrm{Fe}_{3} \mathrm{~S}_{4}\right]^{0}$ core of cluster $1,{ }^{17}$ which is stabilized by tridentate $\mathrm{LS}_{3} .{ }^{24}$ The ideal minimal reaction of cluster formation is the inner sphere redox process 2, leading to a cluster whose $\mathrm{Ni}^{2+}(\mathrm{S}=1)$ $+\left[\mathrm{Fe}_{3} \mathrm{~S}_{4}\right]^{1-}(\mathrm{S}=5 / 2)$ components are antiferromagnetically coupled to give cluster spin $\mathrm{S}=$ $3 / 2$. ${ }^{14}, 15$ However, the same oxidation state occurs in $\mathbf{5}$ and $\mathbf{6}$, which are formed from $\mathrm{Ni}^{2+}$ complexes by reactions in which it is likely that the anionic sulfur ligands act as one-electron reductants. Further, in minimal reaction $3 \mathrm{Ni}^{0}$ complexes afford phosphine clusters $\mathbf{3 - 5}$ and isonitrile cluster 2 , isolated in $93 \%$ yield. Because potentials of the couples $\left[\left(\mathrm{Ph}_{3} \mathrm{P}\right)\right.$ $\left.\mathrm{NiFe}_{3} \mathrm{~S}_{4}(\mathrm{SR})_{3}\right]^{2-/ 3-}$ are highly reducing (ca. $-1.6 \mathrm{~V}$ vs. SCE), ${ }^{15,17}$ it is probable that any $\left[\mathrm{NiFe}_{3} \mathrm{~S}_{4}\right]^{0}$ cluster formed is adventiously oxidized or not formed at all. The disposition of the additional electron is unknown. These observations and others that follow collectively are indicative of the preferential stability of the $\left[\mathrm{NiFe}_{3} \mathrm{~S}_{4}\right]^{1+}$ oxidation state.

$$
\begin{gathered}
{\left[\mathrm{Fe}_{3} \mathrm{~S}_{4}\right]^{0}+\mathrm{Ni}^{1+} \rightarrow\left[\mathrm{NiFe}_{3} \mathrm{~S}_{4}\right]^{1+}} \\
{\left[\mathrm{Fe}_{3} \mathrm{~S}_{4}\right]^{0}+\mathrm{M}^{0} \rightarrow\left[\mathrm{MFe}_{3} \mathrm{~S}_{4}\right]^{1+}+\mathrm{e}^{-}}
\end{gathered}
$$

To obtain a representative structure of an $\left[\mathrm{NiFe}_{3} \mathrm{~S}_{4}\right]^{1+}$ cluster supported by the $\mathrm{LS}_{3}$ ligand, the structure of phosphine cluster 3, shown in Figure 3, was determined. Metric parameters are collected in Table 2 . The cluster, with alternating coordinating arms above $(a)$ and buttressing S-p-tolyl legs below (b) the central benzene ring in the conformation $a b a b a b$, has idealized trigonal symmetry. The bottom of the core at S4 is placed at 3.79(2) $\AA$ above the central ring. Tetrahedral stereochemistry at the $\mathrm{Ni}^{\mathrm{II}} \mathrm{PS}_{3}$ site is made evident by the angles $\mathrm{P}-\mathrm{Ni}-\mathrm{S}=104.7$ $(1)-118.4(1)^{\circ}$ and S-Ni-S = 105.41(9)-106.03(9) ${ }^{\circ}$. The $\mathrm{Me}_{3} \mathrm{P}$ ligand is bound at 2.204(3) from the $\mathrm{Ni}^{\mathrm{II}}$ atom. Note the mean Ni-S distance of 2.263(6) $\AA$. These dimensions compare closely with those of $\left[\left(\mathrm{Ph}_{3} \mathrm{P}\right) \mathrm{NiFe}_{3} \mathrm{~S}_{4}(\mathrm{Smes})_{3}\right]^{1-15}$ Other bond distances and angles are unexceptional.

(b) Reactions at the $\mathrm{Ni}^{\mathrm{Il}}$ Site-Cluster $\mathbf{2}$ was selected to examine reactions at the $\mathrm{Ni}^{\mathrm{II}}$ site. The ${ }^{1} \mathrm{H}$ NMR spectra of $\mathbf{2}$ and $\mathbf{3}$ in Figure 4 illustrate the well-resolved isotropically shifted spectra induced by the $\left[\mathrm{NiFe}_{3} \mathrm{~S}_{4}\right]^{1+}(\mathrm{S}=3 / 2)$ oxidation state bound to $\mathrm{LS}_{3}$. In addition to its formation from $\mathbf{1}$ and $\left[\mathrm{Ni}\left(\mathrm{CNBu}^{t}\right)_{4}\right], \mathbf{2}$ can be obtained by treatment of 5 with 1.1 equiv of the isonitrile. An excess of ligand affords a mixture of $\mathbf{2}$ and previously reported $\left[\mathrm{Fe}_{4} \mathrm{~S}_{4}\left(\mathrm{LS}_{3}\right)\right.$ $\left.\left(\mathrm{Bu}^{t} \mathrm{NC}\right)_{3}\right]^{1-}$, containing a low-spin six-coordinate $\mathrm{Fe}^{\mathrm{II}}$ site. ${ }^{38}$ Treatment of $\mathbf{2}$ with $\left[\mathrm{FeCl}_{4}\right]^{2-}$ and $\left[\mathrm{Fe}(\mathrm{SEt})_{4}\right]^{2-}$ led to nickel removal and formation of $\mathbf{7}$ and $\mathbf{8}$, respectively. Reaction with $\left[\mathrm{MCl}_{4}\right]^{2-}(\mathrm{M}=\mathrm{Co}, \mathrm{Ni})$ also led to 7 ; no evidence for formation of heterometal clusters was obtained. The outcome of these reactions, which must involve cluster dissembly and reformation, is another indication of the stability of the $\left[\mathrm{Fe}_{4} \mathrm{~S}_{4}\right]^{2+}$ core relative to those containing heterometals. Reactions of $\mathbf{2}$ with the chelating ligands bdt, edt, and ndt were intended to introduce low-spin $\mathrm{Ni}^{\mathrm{II}}$ dithiolate sites; however, these reagents or cyanide removed $\mathrm{Ni}^{\mathrm{II}}$ with formation of $\mathbf{1}$. 


\section{Clusters with Planar M"l Sites}

(a) Synthesis-The desired planar $\mathrm{Ni}^{\mathrm{II}}$ site is formed in clusters $\mathbf{9 - 1 1}$ from $\mathbf{2}$ and chelating diphosphines in ligand substitution reactions analogous to reaction 1. By imposition of a strong in-plane ligand field, these reactions result in the transformation of tetrahedral to planar $\mathrm{Ni}^{\mathrm{II}}$ with retention of all core atoms. Conversions to the product clusters in situ are $\gtrsim 90 \%$. Reactions are indicated by the appearance of the free isonitrile resonance and the characteristic spectra of the product clusters (see below). Further experimentation directed toward planar sites led to the development of the metal incorporation reactions in Figure 5. These reactions are of type $3(\mathrm{M}=\mathrm{Ni}, \mathrm{Pd}, \mathrm{Pt})$ and afford the clusters $\mathbf{9 , 1 2}$, and $\mathbf{1 3}$, which were isolated in moderate yields as $\mathrm{Et}_{4} \mathrm{~N}^{+}$salts $(\mathbf{9}, 43 \% ; \mathbf{1 2}, 69 \% ; \mathbf{1 3}, 38 \%)$. While the reactants are potential two-electron reductants, clusters containing $\left[\mathrm{MFe}_{3} \mathrm{~S}_{4}\right]^{1+}$ cores were obtained in all cases. In this and other work, we have found without exception that the use of potential two-electron reductants in metal incorporation reactions results in the delivery of only one electron to the product core. Reactions affording $\mathrm{Ni}^{\mathrm{II}}$ clusters $\mathbf{9 - 1 1}$ by ligand substitution or metal incorporation with accompanying electron transfer are versions of step (i) in the synthesis of the C-cluster. Because metal incorporation into $\mathbf{1}$ produces a cleaner product on a larger reaction scale than does ligand displacement from $\mathbf{2}$ or $\mathbf{5}$, it is the method of choice for the preparation of cluster $\mathbf{9}$.

(b) Structures and Properties-The overall structures of $\mathrm{Pd}^{\mathrm{II}}$ and $\mathrm{Pt}^{\mathrm{II}}$ clusters $\mathbf{1 2}$ and 13, respectively, are shown in Figure 6; selected bond lengths and angles are collected in Table 2. These species are effectively isostructural with $\mathrm{Ni}^{\mathrm{II}}$ cluster $9 .{ }^{16}$ The clusters do not achieve congruency owing mainly to the larger radii of $\mathrm{Pd}^{\mathrm{II}}$ and $\mathrm{Pt}^{\mathrm{II}}$ and differences in $\mathrm{M} \cdots \mathrm{S} *$ separations. The $\mathrm{Et}_{4} \mathrm{~N}^{+}$salts crystallize with two independent cluster anions, both of which have the $a b a b a b$ ligand conformation. The most conspicuous feature of the structures is the presence of planar $\mathrm{M}^{\mathrm{II}} \mathrm{P}_{2} \mathrm{~S}_{2}$ coordination units integrated into the $\mathrm{MFe}_{3} \mathrm{~S}_{4}$ cores. Core structures are presented in more detail in Figure 7. The dihedral angles $\alpha$ and $\beta$ in Table 2 are such that the planes MS1 S3 and $\mathrm{Fe} 2 \mathrm{~S} 2 \mathrm{Fe} 3$ are folded in opposite directions along the $\mathrm{S} 1 \cdots \mathrm{S} 3$ and $\mathrm{Fe} 2 \cdots \mathrm{Fe} 3$ directions, respectively. This results in $\mathrm{M} \cdots \mathrm{S}^{*}(\mathrm{~S} 2, \mathrm{~S} 15)$ axial separations that are much longer than bonded distances (Fe1-S4, Fe2-S1, Fe3-S3) that are roughly parallel to the M-S* vector. The M $\cdots S^{*}$ separations of 3.017(4)-3.392(3) $\AA$ in $\mathbf{1 2}$ and 13, when considered with the data for 9 (2.602(2)-2.901(2) $\AA$ ), further accentuate planar coordination and the variability in axial $\mathrm{S}^{*}$ atom separations for the metal atom. When assessed against complexes of the general type $\left[\mathrm{M}(\mathrm{dppe})(\mathrm{SR})_{2}\right]$ with $\mathrm{M}=\mathrm{Pd}^{\mathrm{II} 39-43}$ and $\mathrm{Pt}^{\mathrm{II}} 43-47$ where the pairs of phosphorus and sulfur atoms are necessarily cis as in the clusters, the metric data for $\mathbf{1 2}$ and 13 indicate normal planar coordination. The P-M-P bite angles of $84.9-86.8^{\circ}$ compare well with the cluster range of $86.3-87.5^{\circ}$ as do the M-P distances $2.25-2.31 \AA$ vs. $2.22-2.24 \AA$ for the clusters. Comparison of M-SR bond distances in the complexes (2.30-2.38 $\AA$ ) and the clusters $(2.39-2.44 \AA)$ is less exact owing to the differences in thiolate vs. $\mu_{3}-S$ atoms, but the values are commensurate. In the $\mathrm{Ni}^{\mathrm{II}}$ cluster $\mathbf{9}$, the $\mathrm{Ni}-\mathrm{S}$ distances are $c a .0 .05-0.10 \AA$ longer than the normal Ni-SR bonds in planar complexes, a situation arising from the semi-rigidity of the $\mathrm{Fe}_{3} \mathrm{~S}_{4}$ portion of the core structure. The larger radii of $\mathrm{Pd}^{\mathrm{II}}(0.78 \AA)$ and $\mathrm{Pt}^{\mathrm{II}}(0.74 \AA)$ vs. planar $\mathrm{Ni}^{\mathrm{II}}(0.69 \AA)^{48}$ may allow an improved fit within the cubanoid core inasmuch as the majority of M-S cluster distances occur near $2.40 \AA$. Whether this matter contributes to the improved stability of $\mathbf{1 2}$ compared to $\mathbf{9}$ is presently unknown. The $\mathrm{Pd}^{\mathrm{II}}$ cluster (more extensively handled than $\mathbf{1 3}$ ) is easier to purify, manipulate, and crystallize than is its $\mathrm{Ni}^{\mathrm{II}}$ analogue.

Consistent with their close structural relationship, the properties of $\mathbf{9 , 1 2}$, and $\mathbf{1 3}$ set out in Table 3 are highly similar. Isomer shifts are nearly identical and correspond to the mean oxidation state $\mathrm{Fe}^{2.33+}$. Redox potentials for reduction of the $\left[\mathrm{MFe}_{3} \mathrm{~S}_{4}\right]^{1+}$ state are indistinguishable; peak potentials for irreversible oxidations show some variability. As illustrated in Figure 8 for $\mathbf{9}$ and $\mathbf{1 2}$, the $\left[\mathrm{MFe}_{3} \mathrm{~S}_{4}\right]^{1+}$ oxidation state with planar $\mathrm{M}^{\mathrm{II}}$ sites when 
bound to $\mathrm{LS}_{3}$ generates a highly characteristic pattern of isotropically shifted resonances in spectra that are readily distinguished from $\left[\mathrm{NiFe}_{3} \mathrm{~S}_{4}\right]^{1+}$ clusters with tetrahedral $\mathrm{Ni}^{\mathrm{II}}$ sites (Figure 4). Chemical shifts of $\mathbf{1 3}$ are $\delta 16.97,16.25$, and 13.40 .

Variable temperature magnetic susceptibility data for polycrystalline $\left(\mathrm{Et}_{4} \mathrm{~N}\right)_{2}[\mathbf{1 2}]$, plotted in Figure 9, were collected to examine the ground state of the cluster. The product $\chi_{\mathrm{m}} \mathrm{T} \approx 4.2 \mathrm{emu}$ $\mathrm{K} \mathrm{mol}^{-1}$ is nearly constant over the $30-300 \mathrm{~K} \mathrm{range} \chi_{\mathrm{m}}^{\mathrm{T}}=4.38 \mathrm{emu} \mathrm{K} \mathrm{mol}^{-1}$ for $\mathrm{S}=5 / 2$.

Magnetic moments calculated from the Curie law at selected temperatures are $5.77 \mu_{\mathrm{B}}(30 \mathrm{~K})$, $5.83 \mu_{\mathrm{B}}(180 \mathrm{~K})$ and $5.98 \mu_{\mathrm{B}}(300 \mathrm{~K})$. The sharp decrease below $30 \mathrm{~K}$ can be ascribed to zerofield splitting effects while the slightly rising trend at $180 \mathrm{~K}$ could arise from the population of levels with high spin multiplicities. Variable field magnetization data over the 2-4 K range (not shown) reveal non-superimposed curves indicative of zero-field splitting. Magnetization data at $2.0 \mathrm{~K}$ approach but do not reach saturation while exceeding a value of $\sim 4 \mathrm{~N} \mu_{\mathrm{B}}$ at $7 \mathrm{~T}$. The collective magnetic data are in accord with an $S=5 / 2$ ground state arising from the $\left[\mathrm{Fe}_{3} \mathrm{~S}_{4}\right]^{1-}$ fragment. This ground state applies to $\mathbf{9}$ as deduced from Mössbauer and EPR spectroscopies whose analysis is complicated owing to structural heterogeneity and lesser stability of clusters. ${ }^{16}$ Clusters $\mathbf{9}$ and $\mathbf{1 2}$ are the only synthetic $\mathrm{Fe}_{3} \mathrm{~S}_{4}$ clusters proven to have the $\mathrm{S}=5 / 2$ ground state. It is highly probable that $\mathrm{Pt}^{\mathrm{II}}$ cluster $\mathbf{1 3}$ has this same ground state. This state has been observed spectroscopically in protein-bound $\left[\mathrm{ZnFe}_{3} \mathrm{~S}_{4}\right]^{1+}$ clusters. ${ }^{49-51}$ The prevailing electronic description invokes a $\mathrm{Fe}^{2.5+} \mathrm{Fe}^{2.5+}$ valence-delocalized pair and a high-spin $\mathrm{Fe}^{\mathrm{II}}$ site. ${ }^{52}$ Because isotropic shifts in Fe-S clusters are dominantly contact in origin and thus proportional to magnetic susceptibility, 53,54 the difference in ground states is responsible for the larger shifts of $\mathbf{9 , 1 2}$ and $\mathbf{1 3}$ vs. 2-5.

(c) Structural Relation to Ch CODH II C-cluster-To examine the structural relationship between the native and synthetic clusters, corresponding core fragments were subjected to bestfit superpositions and weighted rms deviations in atom positions were calculated. The subroutine OFIT of the SHELXL-97 program package was used. The exo iron atom and all bridging and terminal ligand atoms not part of the $\mathrm{NiFe}_{3} \mathrm{~S}_{4}$ core were excluded. The situation is illustrated in Figure 10, where a $\mathrm{NiFe}_{3} \mathrm{~S}_{4}$ cluster was used with a $\mathrm{Ni} \cdots \mathrm{S} *$ separation of 2.60 $\AA .{ }^{16}$ For the $\mathrm{Fe}_{3} \mathrm{~S}_{3}$ portions (excluding $\mathrm{S}^{*}$ ) the deviation is relatively small $(0.088 \AA$ ) and becomes larger for $\mathrm{Fe}_{3} \mathrm{~S}_{4}(0.17 \AA)$ and for $\mathrm{NiFe}_{3} \mathrm{~S}_{4}(0.31 \AA)$. The $\mathrm{Fe}_{3} \mathrm{~S}_{3}$ parts are essentially congruent. The larger rms deviations arise from differences in positions of the $\mathrm{Ni}$ and $\mathrm{S} *$ atoms. In synthetic clusters, the dihedral angles $\alpha$ and $\beta$ (Table 2), involving planes containing $M$ and $\mathrm{S}^{*}$ atoms, are apparently subject to crystalline effects. In the two crystallographically inequivalent clusters of $12, \alpha=23.0^{\circ}$ and $31.9^{\circ}$ and $\beta=24.2^{\circ}$ and $29.4^{\circ}$, resulting in $\mathrm{M} \cdots \mathrm{S}^{*}$ distances of 3.017(4) $\AA$ and 3.271(4) $\AA$, respectively. Comparable differences in dihedral angles are found with the clusters of 13, where the distances are 3.107(3) $\AA$ and 3.392(3) $\AA$. On this basis, it would seem plausible that $\mathrm{Ni} \cdots \mathrm{S} *$ distances are influenced by protein structure and environment.

\section{Site-Differentiated $\mathrm{Fe}_{4} \mathrm{~S}_{4}$ Clusters}

In further attempts to construct a planar $\mathrm{Ni}^{\mathrm{II}}$ site, clusters $\mathbf{2}$ and $\mathbf{5}$ were reacted in acetonitrile with potential bidentate chelate ligands containing one thiolate. Reactions were monitored by ${ }^{1} \mathrm{H}$ NMR spectroscopy. When $\mathbf{5}$ was treated with $c a$. 1 equiv of the sodium salts of $\mathrm{R}_{2} \mathrm{PCH}_{2} \mathrm{CH}_{2} \mathrm{SH}(\mathrm{R}=\mathrm{Me}, \mathrm{Ph}), 1,2-\mathrm{Ph}_{2} \mathrm{PC}_{6} \mathrm{H}_{4} \mathrm{SH}$, and $\mathrm{Me}_{2} \mathrm{NCH}_{2} \mathrm{CH}_{2} \mathrm{SH}$, gradual formation of $\left[\mathrm{Fe}_{4} \mathrm{~S}_{4}\right]^{2+}$ clusters with ligand bound to the subsite-differentiated iron site was observed (see below). Reactions with 2 led mainly to removal of nickel and formation of cuboidal cluster 1. In no case was a cluster containing a planar $\mathrm{Ni}^{\mathrm{II}}$ site detected.

In order to characterize two of the foregoing reaction products, the reactions of Figure 11 were pursued. The 3:1 site-differentiated cluster 7 reacted smoothly with the specified phosphino- 
or aminothiolate to afford clusters $\mathbf{1 5}(76 \%)$ and $\mathbf{1 6}(80 \%)$, isolated in the indicated yields as $\mathrm{Et}_{4} \mathrm{~N}^{+}$salts. In addition, the more soluble compounds $\left(\mathrm{Bu}_{4} \mathrm{~N}\right)_{2}[\mathbf{1 5}](82 \%)$ and $\left(\mathrm{Bu}_{4} \mathrm{~N}\right)_{2}[\mathbf{1 6}]$ $(77 \%)$ were prepared. The ${ }^{57} \mathrm{Fe}$ isomer shifts $\delta=0.44-0.45 \mathrm{~mm} / \mathrm{s}$ identify the $\left[\mathrm{Fe}_{4} \mathrm{~S}_{4}\right]^{2+}$ oxidation state, 55 thiolate binding is confirmed by downfield-shifted $\mathrm{SCH}_{2}$ resonances at 12.05 (15) and $20.90(\mathbf{1 6}), 36$ and the reduction potentials of $-1.11 \mathrm{~V} \mathrm{(15)}$ and $-1.14 \mathrm{~V}(\mathbf{1 6})$ are consistent with alkylthiolate ligation. ${ }^{22,56}$ Trimethylphosphine cluster $\mathbf{1 4}$ (analogous to $\mathbf{3}$ ) was generated in solution. Its 5-H (8.19) and 4-,6-Me (3.86,3.83) chemical shifts compared to those of $\mathbf{1 5}(8.16,3.83,3.71)$ indicate that $\mathrm{LS}_{3}$ resonances do not allow assignment of Fe-SR vs. $\mathrm{Fe}-\mathrm{PR}_{3}$ binding in this case; the $\mathrm{SCH}_{2}$ shift is unambiguous in this respect.

The compound $\left(\mathrm{Et}_{4} \mathrm{~N}\right)_{2}[\mathbf{1 6}]$ as the acetonitrile solvate crystallizes with two inequivalent clusters in the asymmetric unit. Both have the same overall structure, shown in Figure 12, with the ligand in the $a b a b a b$ conformation. The most interesting feature is the coordination at the unique site, depicted for both clusters, where the aminothiolate ligand forms a chelate ring with a normal or perhaps slightly elongated (by $\lesssim 0.05 \AA$ ) Fe-S bond and a substantially longer Fe$\mathrm{N}$ bond. This is one of the few isolated $\left[\mathrm{Fe}_{4} \mathrm{~S}_{4}\right]^{2+}$ clusters which have been shown to have fiveor six-coordination at the unique site, $18,21-23,57$ and the only such cluster with a structurally defined $\mathrm{FeS}_{4}$ Nunit. Retention of a chelated structure in solution is apparently the cause of the strongly downfield-shifted $\mathrm{SCH}_{2}$ signal. Five- or six-coordinate sites in $\left[\mathrm{Fe}_{4} \mathrm{~S}_{4}\right]^{2+}$ are usually reflected by isomer shifts above $c a .0 .50 \mathrm{~mm} / \mathrm{s}$ at $4.2 \mathrm{~K} .^{21,55}$ Evidently, Fe-N binding at $2.42-$ $2.47 \mathrm{~A}$ is an insufficient perturbation on the $\mathrm{FeS}_{4}$ site to influence the Mossbauer parameters. Attempts to obtain diffraction quality crystals containing 15 were not successful. However, in one such attempt adventitious oxidation led to crystallization of the phosphine oxide cluster 17 as the $\mathrm{Et}_{4} \mathrm{~N}^{+}$salt acetonitrile hemisolvate. The cluster structure, presented in Figure 13 reveal binding only by thiolate at the unique site, and a case of the unusual ligand conformation aaaaab. Cluster dimensions of 16 and 17, summarized in Table 4, are unexceptional. ${ }^{37}$

\section{Summary}

The following are the principal results and conclusions of this investigation, together with certain results from previous work.

1. Cubane-type $\left[\mathrm{NiFe}_{3} \mathrm{~S}_{4}\right]^{1+}$ clusters containing tetrahedral $\mathrm{Ni}^{\mathrm{II}}$ sites can be formed by two procedures: (i) metal ion incorporation into cuboidal $\left[\mathrm{Fe}_{3} \mathrm{~S}_{4}\left(\mathrm{LS}_{3}\right)\right]^{3-}$ by reaction with $\mathrm{Ni}^{0}, \mathrm{Ni}^{\mathrm{I}}{ }^{17}$ or $\mathrm{Ni}^{\mathrm{II}} / \mathrm{RS}^{-}$species; (ii) reaction of $\mathrm{Ni}^{0}$ species with linear $\left[\mathrm{Fe}_{3} \mathrm{~S}_{4}(\mathrm{SR})_{4}\right]^{3-} .14,15$ Product clusters are of the general type $\left[\mathrm{LNiFe}_{3} \mathrm{~S}_{4}(\mathrm{SR})_{3}\right]^{2-}(\mathrm{L}$ $\left.=\mathrm{R}_{3} \mathrm{P}, \mathrm{RNC}\right)$. The procedures are examples of cluster formation by fragment condensation, with (ii) including the subsequent step of core rearrangement. ${ }^{58}$

2. The clusters in (1) undergo a limited set of substitution reactions at the $\mathrm{Ni}^{\mathrm{II}}$ site, including displacement of $\mathrm{Ph}_{3} \mathrm{P}$ by $\mathrm{Bu}^{t} \mathrm{NC}, \mathrm{R}_{3} \mathrm{P}$, and $\mathrm{RS}^{-},{ }^{14} \mathrm{Bu}^{t} \mathrm{NC}$ by $\mathrm{R}_{3} \mathrm{P}(\mathrm{R}=$ alkyl), and metal removal by chelating dithiolates to give the cuboidal $\left[\mathrm{Fe}_{3} \mathrm{~S}_{4}\right]^{0}$ cluster.

3. Cubanoid $\left[\mathrm{NiFe}_{3} \mathrm{~S}_{4}\right]^{1+}$ clusters containing planar $\mathrm{Ni}^{\mathrm{II}}$ sites are accessible by two procedures: (i) displacement of $\mathrm{Ph}_{3} \mathrm{P}$ with the chelating diphosphines $\mathrm{R}_{2} \mathrm{PCH}_{2} \mathrm{CH}_{2} \mathrm{PR}_{2}\left(\mathrm{R}=\mathrm{Me},{ }^{16} \mathrm{Et}, \mathrm{Ph}\right)$; (ii) metal atom incorporation into $\left[\mathrm{Fe}_{3} \mathrm{~S}_{4}\left(\mathrm{LS}_{3}\right)\right]^{3-}$ using a Ni ${ }^{0}$ reactant in the presence of $\mathrm{Me}_{2} \mathrm{PCH}_{2} \mathrm{CH}_{2} \mathrm{PMe} 2$. Procedure (ii) with $\mathrm{Pd}^{0}$ and $\mathrm{Pt}^{0}$ affords the analogous clusters [(dmpe) $\left.\mathrm{M}^{\mathrm{II}} \mathrm{Fe}_{3} \mathrm{~S}_{4}\left(\mathrm{LS}_{3}\right)\right]^{2-}$.

4. The most conspicuous structural features of the product clusters in (3) are planar diamagnetic $\mathrm{MP}_{2} \mathrm{~S}_{2}$ coordination units with variable separations of the metal ion from an axial $\mu_{2}$-S atom; $\mathrm{M} \cdots \mathrm{S}^{*}=2.60-2.90 \AA(\mathrm{Ni}) ;{ }^{16} 3.02,3.27 \AA$ (Pd); 3.11, $3.39 \AA$ (Pt). Reaction (i) in (3) results in a tetrahedral/planar structural change with retention 
of core atoms. Planar stereochemistry is stabilized by a strong in-plane ligand field at $\mathrm{Ni}^{\mathrm{II}}$ and is the dominant structural preference for $\mathrm{Pd}^{\mathrm{II}}$ andPt ${ }^{\mathrm{II}}$.

5. The $\left[\mathrm{NiFe}_{3} \mathrm{~S}_{4}\right]^{1+}$ oxidation level with tetrahedral $\mathrm{Ni}^{\mathrm{II}}$ has an $\mathrm{S}=3 / 2$ ground state arising from antiferromagnetic coupling of $\mathrm{S}=1\left(\mathrm{Ni}^{2+}\right)$ and $\mathrm{S}=5 / 2\left(\left[\mathrm{Fe}_{3} \mathrm{~S}_{4}\right]^{1-}\right),{ }^{15}$, 50,59 while $\left[\mathrm{NiFe}_{3} \mathrm{~S}_{4}\right]^{1+}$ with planar $\mathrm{Ni}^{\mathrm{II}}$ has an $\mathrm{S}=5 / 2$ ground state, previously observed in protein-bound $\left[\mathrm{ZnFe}_{3} \mathrm{~S}_{4}\right]^{1+}$ clusters. This statement is supported by the magnetism of $\left[(\mathrm{dmpe}) \mathrm{PdFe}_{3} \mathrm{~S}_{4}\left(\mathrm{LS}_{3}\right)\right]^{2-}$. Consequently, the two structural isomers of the $\left[\mathrm{NiFe}_{3} \mathrm{~S}_{4}\right]^{1+}$ core are conveniently distinguished by their isotropically shifted ${ }^{1} \mathrm{H}$ NMR spectra.

This work and that preceding it ${ }^{16}$ demonstrate that a planar $\mathrm{M}^{\mathrm{II}}$ site can be stabilized within the $\left[\mathrm{MFe}_{3} \mathrm{~S}_{4}\right]^{1+}$ cubanoid core. A planar $\mathrm{Ni}^{\mathrm{II}}$ site is a structural element of at least the $\mathrm{C}$-cluster of $C h \mathrm{CODH}$ II (Figure 1). Hence, the feasibility of step (i) in the synthesis of the C-cluster structure is demonstrated. To proceed further, it will be necessary to incorporate bridging atoms, perhaps in physiologically credible bidentate ligands, that promote binding of the exo iron atom to form the full $\mathrm{NiFe}_{4} \mathrm{~S}_{5}$ core. Clusters $\mathbf{9 , 1 2}$, and $\mathbf{1 3}$ first offer the possibility of examining the metal binding affinity of the $S^{*}$ atom positioned at 2.6-3.4 $\AA$ from the heterometal site.

\section{Supplementary Material}

Refer to Web version on PubMed Central for supplementary material.

\section{Acknowledgements}

This research was supported by NIH Grant GM 28856. We thank Professor K. R. Dunbar for generous access to the magnetometer and Dr. S. C. Lee for useful discussions.

\section{References}

1. Ragsdale SW, Kumar M. Chem Rev 1996;96:2515-2539. [PubMed: 11848835]

2. Lindahl PA. Biochemistry 2002;41:2097-2105. [PubMed: 11841199]

3. Grahame DA. Trends Biochem Sci 2003;28:221-224. [PubMed: 12765830]

4. Doukov TI, Iverson TM, Seravalli J, Ragsdale SW, Drennan CL. Science 2002;298:567-572. [PubMed: 12386327]

5. Darnault C, Volbeda A, Kim EJ, Legrand P, Vernède X, Lindahl PA, Fontecilla-Camps JC. Nature Struct Biol 2003;10:271-279. [PubMed: 12627225]

6. Bramlett MR, Tan X, Lindahl PA. J Am Chem Soc 2003;125:9316-9317. [PubMed: 12889960]

7. Seravalli J, Xiao Y, Gu W, Cramer SP, Antholine WE, Krymov V, Gerfern GJ, Ragsdale SW. Biochemistry 2004:3944-3955. [PubMed: 15049702]

8. Lee SC, Holm RH. Proc Natl Acad Sci USA 2003;100:3595-3600. [PubMed: 12642670]

9. Abbreviations are given in the Chart.

10. Dobbek H, Svetlitchnyi V, Liss J, Meyer O. J Am Chem Soc 2004;126:5382-5387. [PubMed: 15113209]

11. Dobbek H, Svetlitchnyi V, Gremer L, Huber R, Meyer O. Science 2001;293:1281-1285. [PubMed: 11509720]

12. Gu W, Seravalli J, Ragsdale SW, Cramer SP. Biochemistry 2004;43:9029-9035. [PubMed: 15248760]

13. Feng J, Lindahl PA. J Am Chem Soc 2004;126:9094-9100. [PubMed: 15264843]

14. Ciurli S, Ross PK, Scott MJ, Yu SB, Holm RH. J Am Chem Soc 1992;114:5415-5423.

15. Zhou J, Scott MJ, Hu Z, Peng G, Münck E, Holm RH. J Am Chem Soc 1992;114:10843-10854.

16. Panda R, Zhang Y, McLauchlan CC, Rao PV, Tiago de Oliveira FA, Münck E, Holm RH. J Am Chem Soc 2004;126:6448-6459. [PubMed: 15149242] 
17. Zhou J, Raebiger JW, Crawford CA, Holm RH. J Am Chem Soc 1997;119:6242-6250.

18. Rao PV, Bhaduri S, Jiang J, Holm RH. Inorg Chem 2004;43:5833-5849. [PubMed: 15360232]

19. Rao PV, Bhaduri S, Jiang J, Hong D, Holm RH. J Am Chem Soc 2005;127:1933-1945. [PubMed: 15701028]

20. Weigel JA, Holm RH. J Am Chem Soc 1991;113:4184-4191.

21. Ciurli S, Carrié M, Weigel JA, Carney MJ, Stack TDP, Papaefthymiou GC, Holm RH. J Am Chem Soc 1990;112:2654-2664.

22. Zhou C, Holm RH. Inorg Chem 1997;36:4066-4077.

23. Liu HY, Scharbert B, Holm RH. J Am Chem Soc 1991;113:9529-9539.

24. Stack TDP, Holm RH. J Am Chem Soc 1988;110:2484-2494.

25. Zhou J, Hu Z, Münck E, Holm RH. J Am Chem Soc 1996;118:1966-1980.

26. Ittel SD. Inorg Syn 1990;28:98-104.

27. Chatt J, Dilworth JR, Schmutz JA. J Chem Soc Dalton Trans 1979:1595-1599.

28. Shields TC, Kurtz AN. J Am Chem Soc 1969;91:5415-5416.

29. Wenschuh E, Wilhelm D, Hartung H, Baumeister U. Z Anorg Allgem Chem 1994;620:2048-2052. 30. Hagen KS, Watson AD, Holm RH. J Am Chem Soc 1983;105:3905-3913.

31. Davison A, Edelstein N, Holm RH, Maki AH. Inorg Chem 1964;3:814-823.

32. Gill NS, Taylor FB. Inorg Syn 1967;9:136-142.

33. Yamamoto T, Sekine Y. Inorg Chim Acta 1984;83:47-53.

34. Kita M, Yamamoto T, Kashiwabara K, Fujita J. Bull Chem Soc Jpn 1992;65:2272-2274.

35. Block E, Ofori-Okai G, Zubieta J. J Am Chem Soc 1989;111:2327-2329.

36. Cai L, Holm RH. J Am Chem Soc 1994;116:7177-7188.

37. See paragraph at the end of this article for Supporting Information available.

38. Weigel JA, Srivastava KKP, Day EP, Münck E, Holm RH. J Am Chem Soc 1990;112:8015-8023.

39. Wei G, Liu H. Acta Crystallogr 1990;C46:2457-2458.

40. Landis KG, Hunter AD, Wagner TR, Curtin LS, Filler FL, Jansen-Varnum SA. Inorg Chim Acta 1998;282:155-162.

41. Su W, Hong M, Cao R, Liu H. Acta Crystallogr 1997;C53:66-67.

42. Singhal A, Jain VK, Varghese B, Tiekink ERT. Inorg Chim Acta 1999;285:190-196.

43. Lobana TS, Verma R, Hundal G, Castineiras A. Polyhedron 2000;19:899-906.

44. Briant CE, Calhorda MJ, Hor TSA, Howells ND, Mingos DMP. J Chem Soc, Dalton Trans 1983:1325-1330.

45. Bevilacqua JM, Zuleta JA, Eisenberg R. Inorg Chem 1994;33:258-266.

46. Wei G, Huang Z, Hong M, Liu H. Jiegou Huaxue (J Struct Chem) 1991;10:159-161.

47. Mas-Ballesté R, Aullón G, Champkin PA, Clegg W, Mégret C, González-Duarte P, Lledós A. ChemEur J 2003;9:5023-5035.

48. Shannon RD. Acta Crystallogr 1976;A32:751-767.

49. Surerus KK, Münck E, Moura I, Moura JJG, LeGall J. J Am Chem Soc 1987;109:3805-3807.

50. Srivastava KKP, Surerus KK, Conover RC, Johnson MK, Park JB, Adams MWW, Münck E. Inorg Chem 1993;32:927-936.

51. Finnegan MG, Conover RC, Park JB, Zhou ZH, Adams MWW, Johnson MK. Inorg Chem 1995;34:5358-5369.

52. Belinsky MI. Chem Phys 2001;263:279-300.

53. Reynolds JG, Laskowski EJ, Holm RH. J Am Chem Soc 1978;100:5315-5322.

54. Bertini I, Ciurli S, Luchinat C. Struct Bonding 1995;83:1-53.

55. Rao PV, Holm RH. Chem Rev 2004;104:527-559. [PubMed: 14871134]

56. DePamphilis BV, Averill BA, Herskovitz T, Que L Jr, Holm RH. J Am Chem Soc 1974;96:41594167. [PubMed: 4854591]

57. Osterloh F, Saak W, Haase D, Pohl S. Chem Commun 2000:777-778.

58. Lee SC, Holm RH. Chem Rev 2004;104:1135-1157. [PubMed: 14871151] 
59. Johnson MK, Duderstadt RE, Duin EC. Adv Inorg Chem 1999;47:1-82. 


\section{STRUCTURES OF C-CLUSTERS}

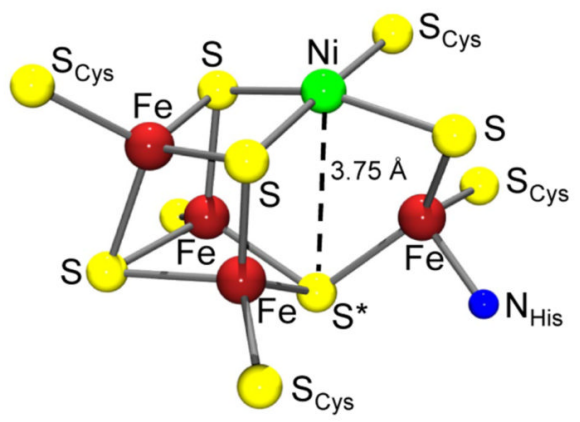

dithionite-reduced C.hydrogenoformans CODH II $1.1 \AA$

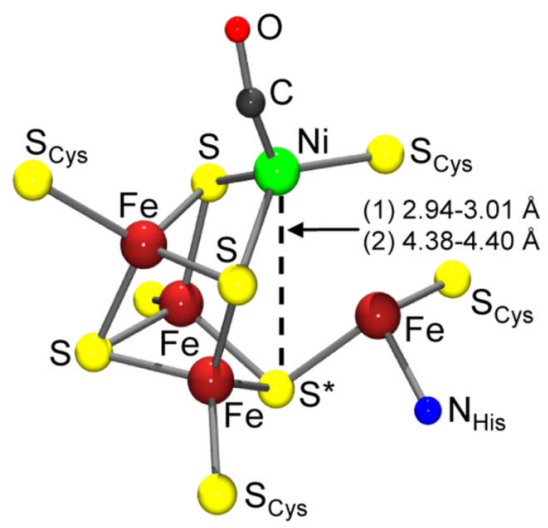

1) M. thermoacetica CODH $2.2 \AA$

2) CO-treated M. thermoacetica CODH $1.9 \AA$

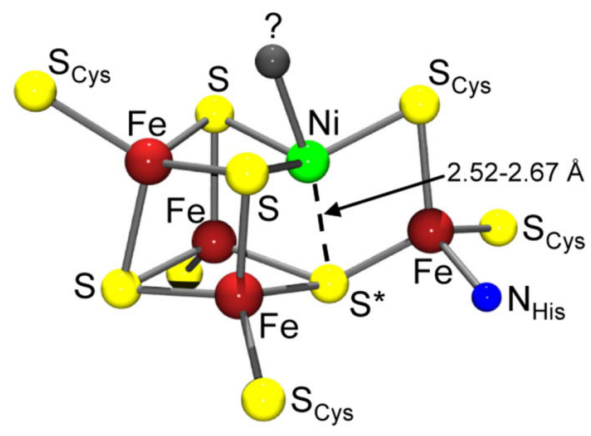

R. rubrum $\mathrm{CODH} 2.8 \AA$

Figure 1.

Crystallographic structures of the C-clusters in enzymes from three organisms determined at the indicated resolutions. The axial $\mathrm{Ni} \cdots \mathrm{S}^{*}$ distances are calculated from coordinates in the Protein Data Base; ranges apply to cases with inequivalent clusters. A CO ligand modeled at nickel is included and a possible persulfide ligand at iron is omitted in Mt CODH (2). 


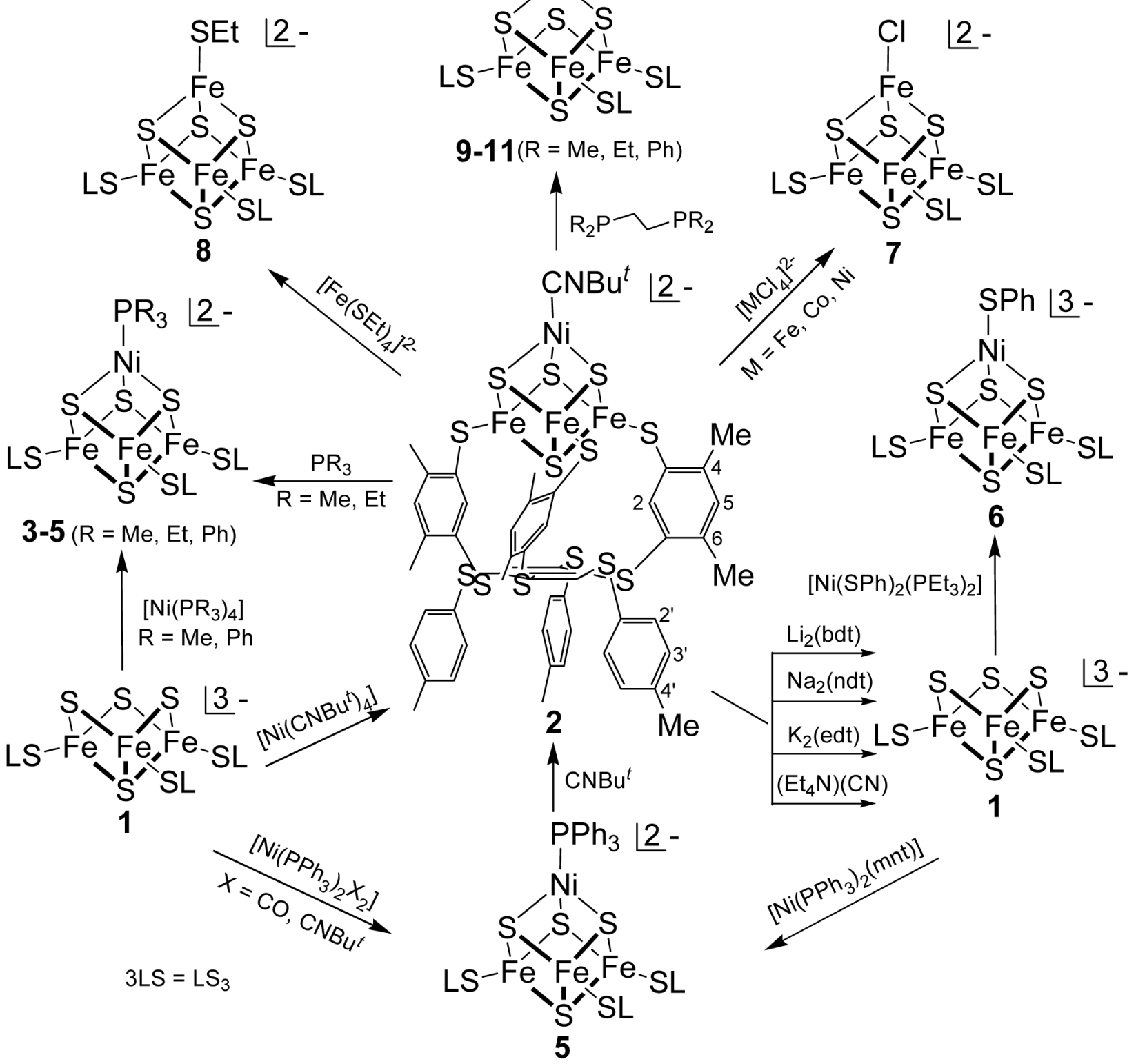

Figure 2.

Scheme showing the synthesis and reactions of $\left[\left(\mathrm{Bu}^{t} \mathrm{NC}\right) \mathrm{NiFe}_{3} \mathrm{~S}_{4}\left(\mathrm{LS}_{3}\right)\right]^{2-}(\mathbf{2})$ from

$\left[\mathrm{Fe}_{3} \mathrm{~S}_{4}\left(\mathrm{LS}_{3}\right)\right]^{3-}$ (1) leading to $\left[\mathrm{NiFe}_{3} \mathrm{~S}_{4}\right]^{1+}(\mathbf{3 - 6 , 9 - 1 1})$ and $\left[\mathrm{Fe}_{4} \mathrm{~S}_{4}\right]^{2+}$ clusters $(\mathbf{7 , 8})$; note the $\mathrm{LS}_{3}$ ligand numbering scheme. 
$\left[\left(\mathrm{Me}_{3} \mathrm{P}\right) \mathrm{NiFe}_{3} \mathrm{~S}_{4}\left(\mathrm{LS}_{3}\right)\right]^{2-}$

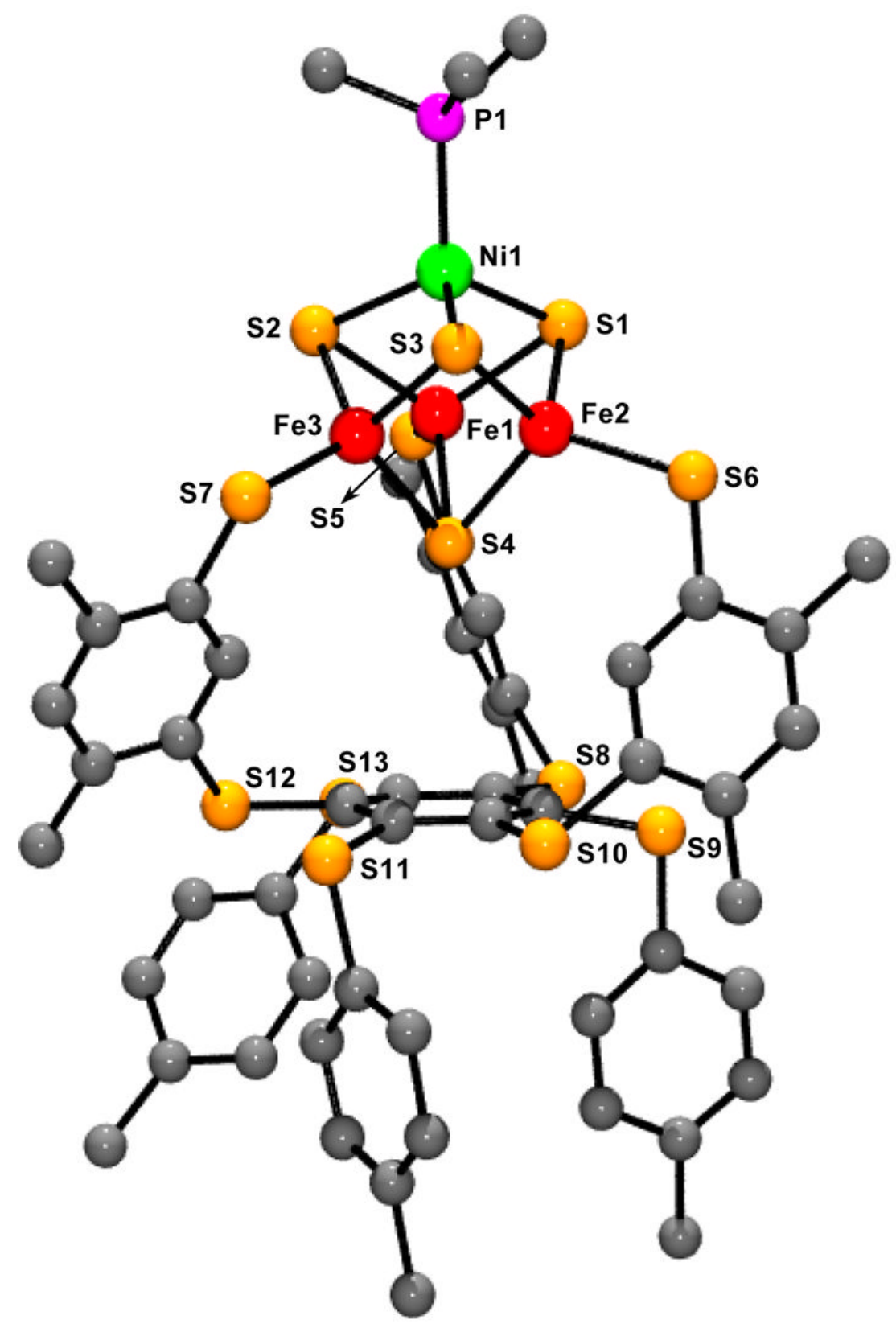

Figure 3.

Structure of $\left[\left(\mathrm{Me}_{3} \mathrm{P}\right) \mathrm{NiFe}_{3} \mathrm{~S}_{4}\left(\mathrm{LS}_{3}\right)\right]^{2-}$ with partial atom labeling scheme. The ligand has the $a b a b a b$ conformation. 


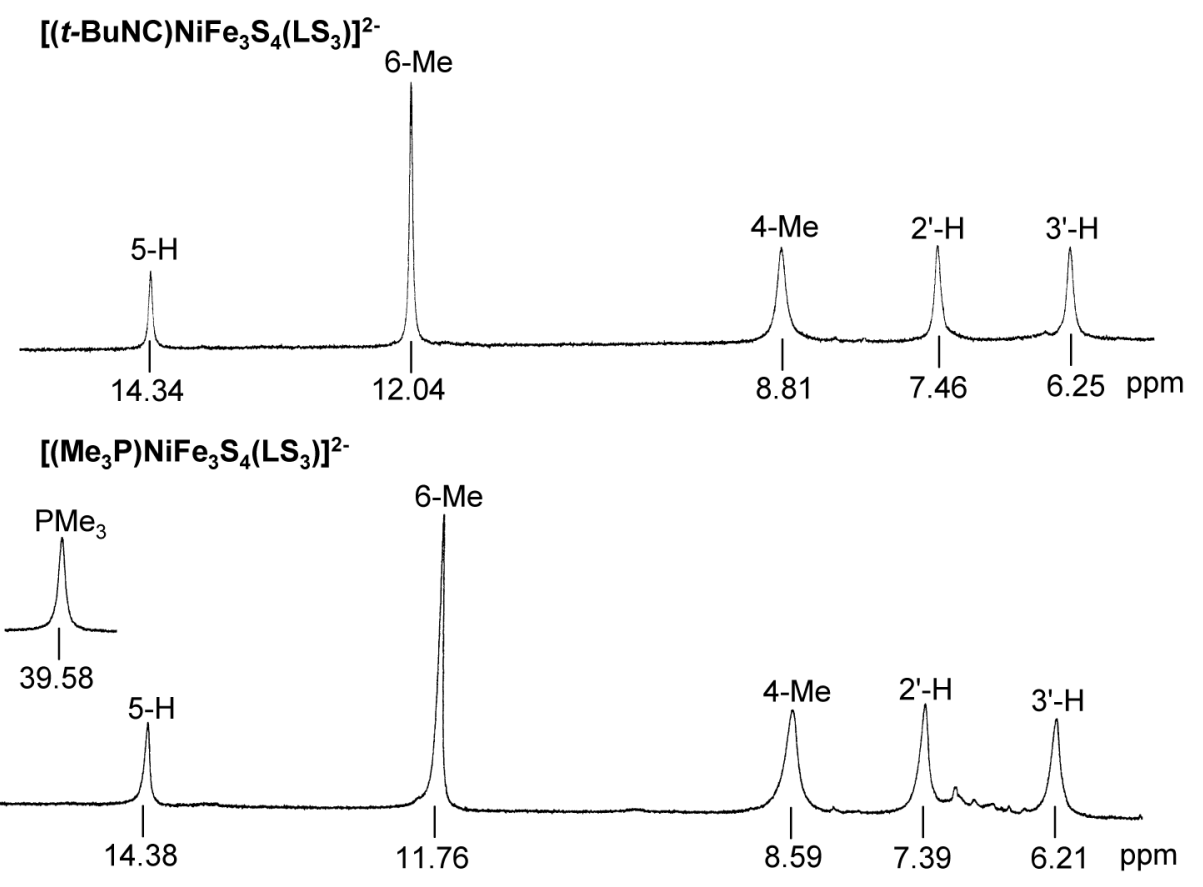

Figure 4.

${ }^{1} \mathrm{H}$ NMR spectra of $\left[\left(\mathrm{Bu}^{t} \mathrm{NC}\right) \mathrm{NiFe}_{3} \mathrm{~S}_{4}\left(\mathrm{LS}_{3}\right)\right]^{2-}$ (upper) and $\left[\left(\mathrm{Me}_{3} \mathrm{P}\right) \mathrm{NiFe}_{3} \mathrm{~S}_{4}\left(\mathrm{LS}_{3}\right)\right]^{2-}$ (lower) in $\mathrm{CD}_{3} \mathrm{CN}$ solutions at $\sim 298 \mathrm{~K}$. Signal assignments are indicated. The $4^{\prime}-\mathrm{Me}$ signals of the isonitrile $(\delta 2.30)$ and phosphine $(\delta 2.28)$ clusters are not shown. 


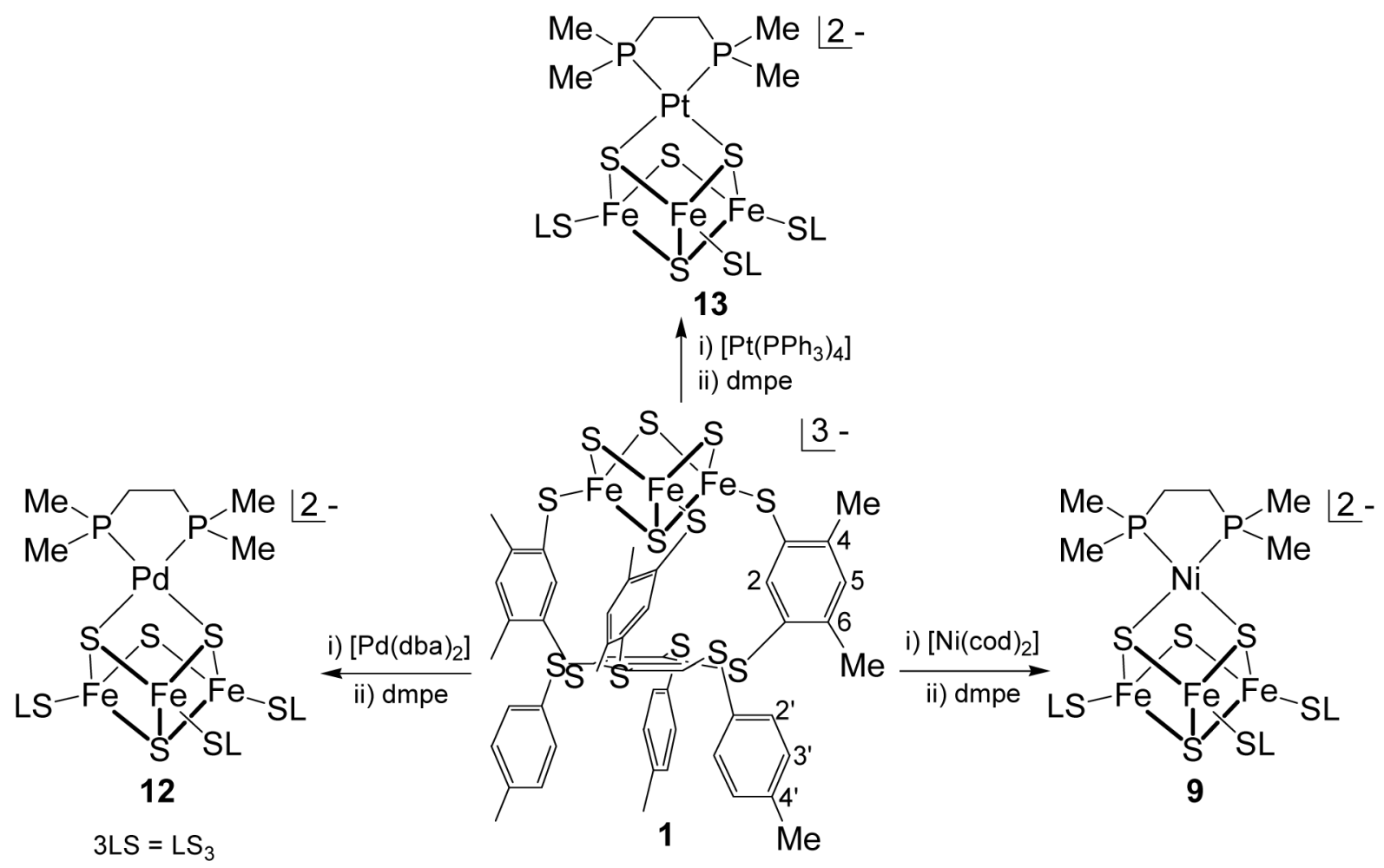

Figure 5.

Synthesis of the clusters $\left[(\mathrm{dmpe}) \mathrm{MFe}_{3} \mathrm{~S}_{4}\left(\mathrm{LS}_{3}\right)\right]^{2-}(\mathrm{M}=\mathrm{Ni}(\mathbf{9}), \mathrm{Pd}(\mathbf{1 2}), \mathrm{Pt}(\mathbf{1 3}))$ from cuboidal $\left[\mathrm{Fe}_{3} \mathrm{~S}_{4}\left(\mathrm{LS}_{3}\right)\right]^{3-}(\mathbf{1}), \mathrm{M}^{0}$ reactants, and dmpe. 


\section{$\left[(\mathrm{dmpe}) \mathrm{MFe}_{3} \mathrm{~S}_{4}\left(\mathrm{LS}_{3}\right)\right]^{2-}$}

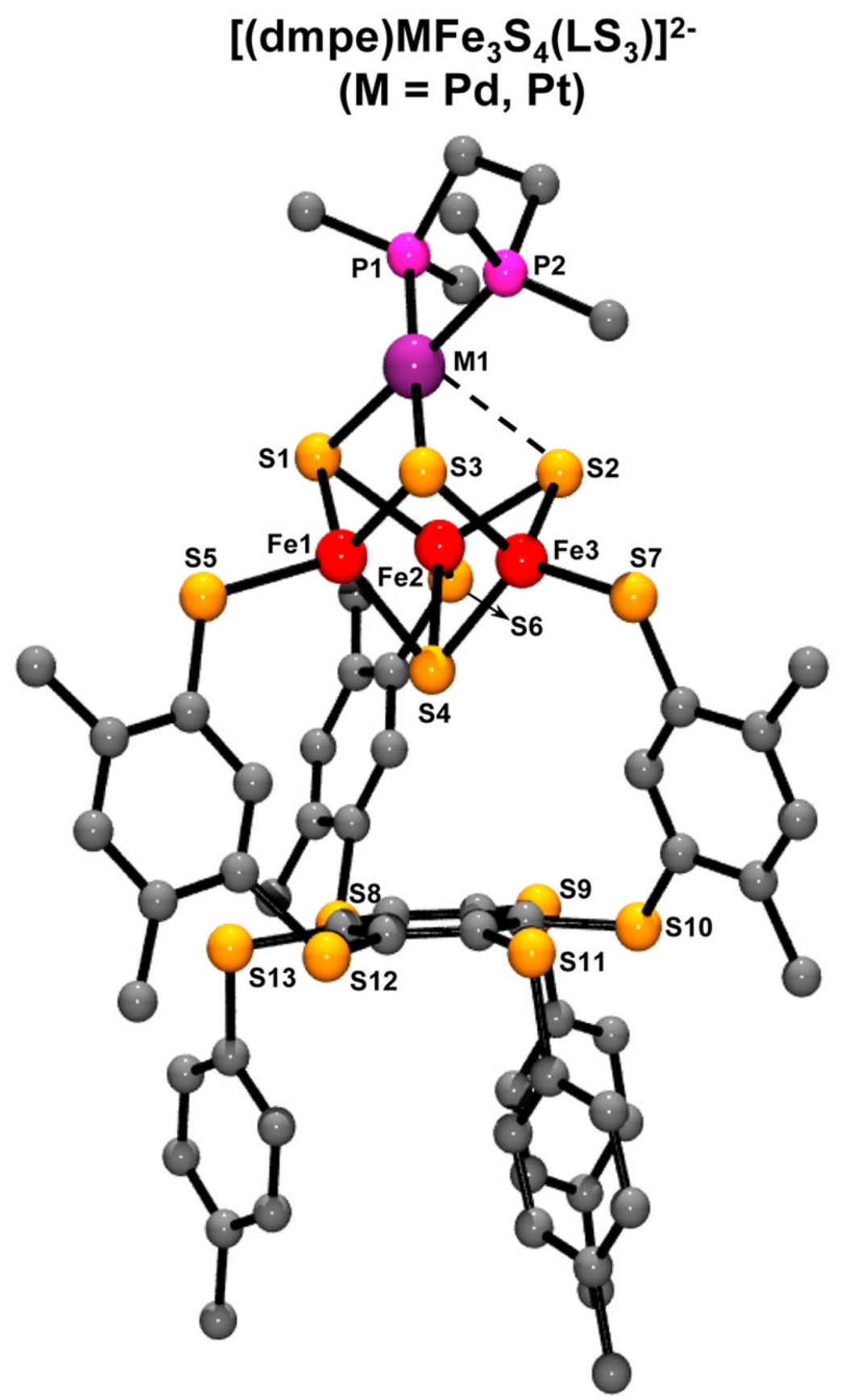

Figure 6.

Structure of one of two inequivalent clusters of $\left[(\mathrm{dmpe}) \mathrm{MFe}_{3} \mathrm{~S}_{4}\left(\mathrm{LS}_{3}\right)\right]^{2-}(\mathrm{M}=\mathrm{Pd}$, Pt $)$ with partial atom labeling schemes. The ligand has the ababab conformation. 


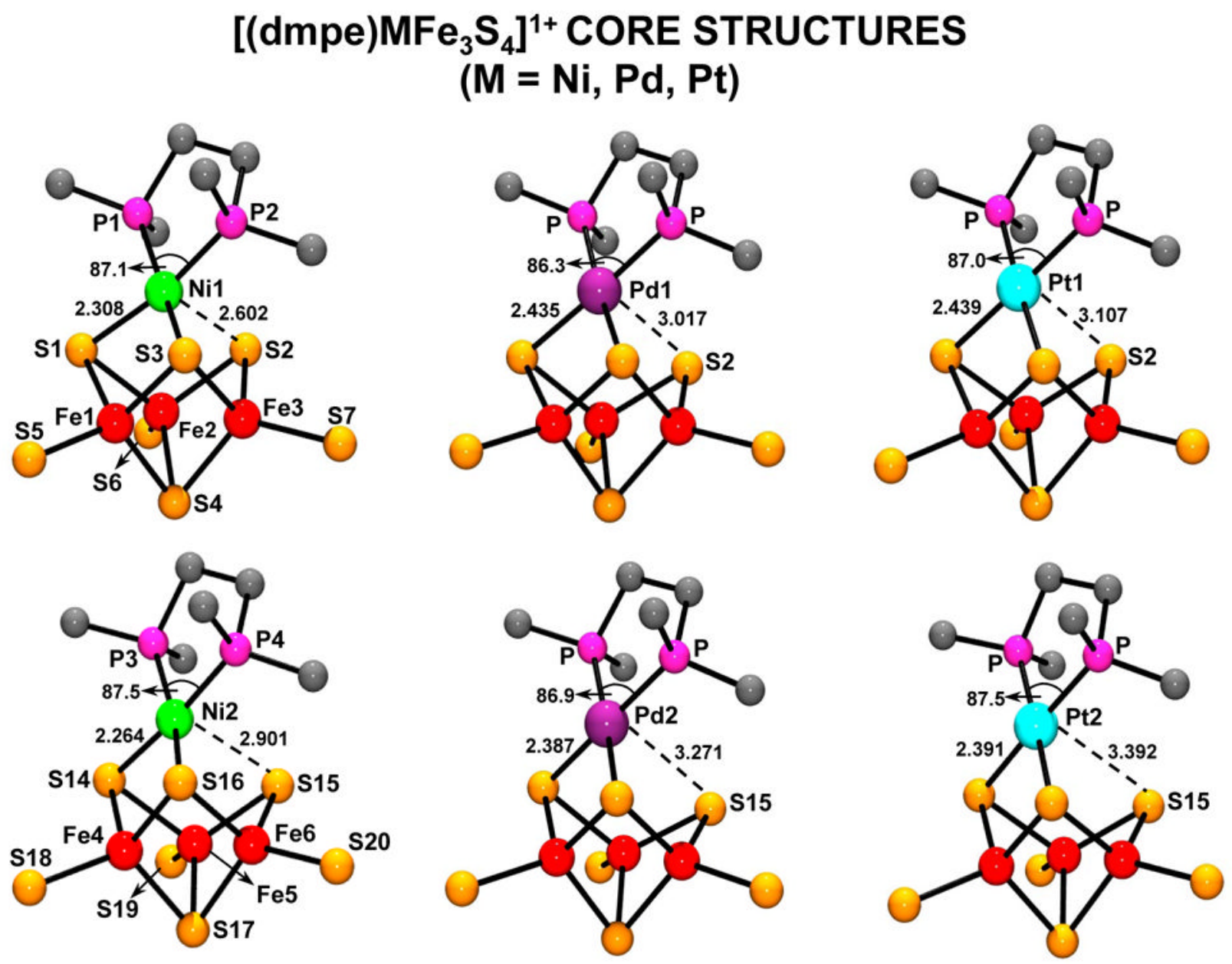

Figure 7.

Core structures $\left[(\mathrm{dmpe}) \mathrm{MFe}_{3} \mathrm{~S}_{4}\right]^{1+}(\mathrm{M}=\mathrm{Ni}, \mathrm{Pd}, \mathrm{Pt})$ of two inequivalent clusters within the asymmetric unit showing selected interatomic distances $(\AA)$ and angles (deg). The atom numbering schemes of the Ni clusters apply to the Pd and Pt clusters. Note the planar coordination units and the long $\mathrm{M} \cdots \mathrm{S} *(\mathrm{~S} 2 / \mathrm{S} 15)$ axial separations. 


\section{[(dmpe) $\left.\mathrm{NiFe}_{3} \mathrm{~S}_{4}\left(\mathrm{LS}_{3}\right)\right]^{2-}$}

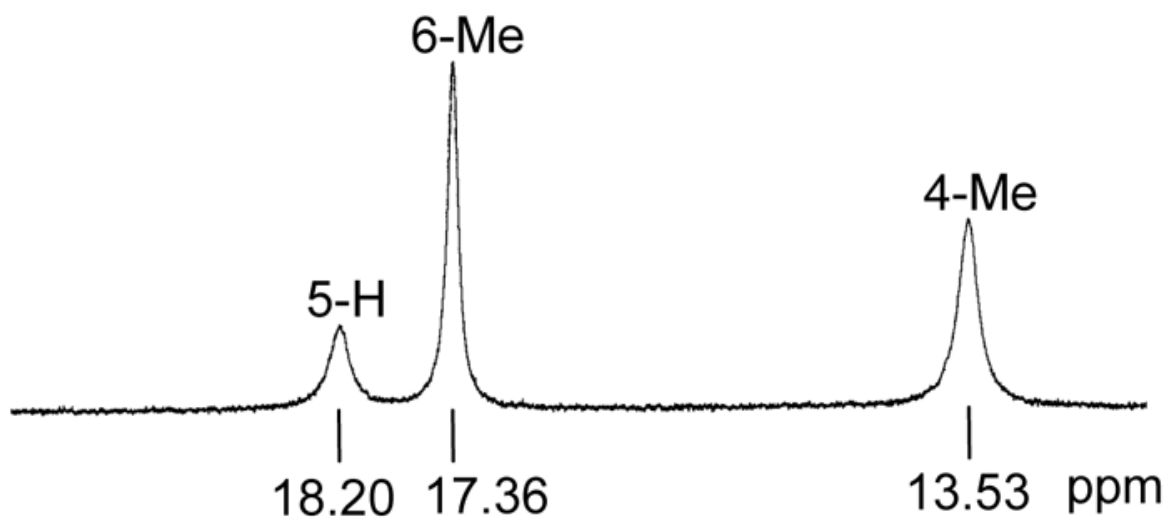

$\left[(\mathrm{dmpe}) \mathrm{PdFe}_{3} \mathrm{~S}_{4}\left(\mathrm{LS}_{3}\right)\right]^{2-}$

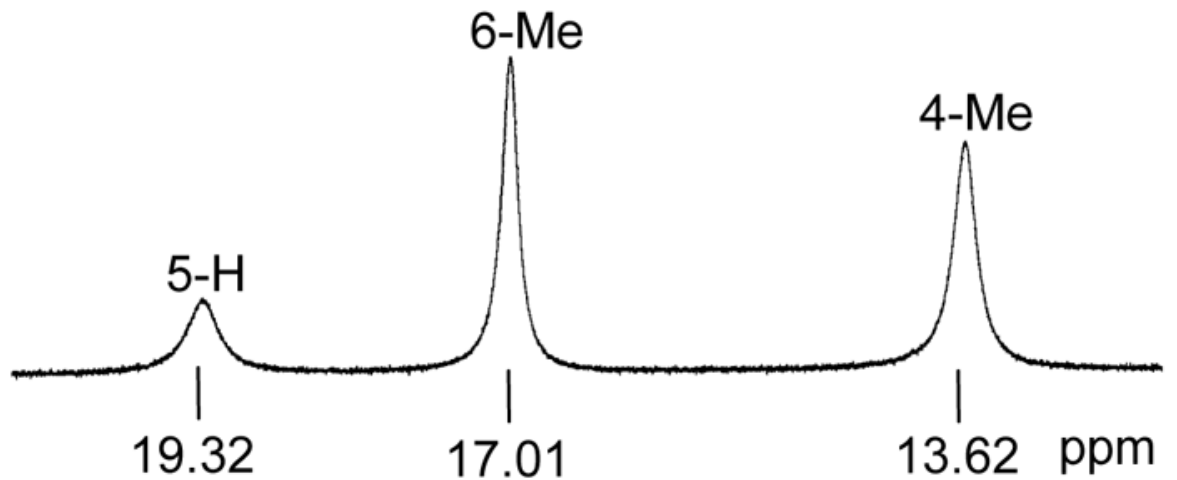

Figure 8.

Comparison of the low-field ${ }^{1} \mathrm{HNMR}$ spectra of $\left[(\mathrm{dmpe}) \mathrm{MFe}_{3} \mathrm{~S}_{4}\left(\mathrm{LS}_{3}\right)\right]^{2-} \mathrm{M}=\mathrm{Ni}$ (upper) and $\mathrm{Pd}$ (lower) in $\mathrm{CD}_{3} \mathrm{CN}$ solutions at $298 \mathrm{~K}$. Only the 5-H, 6-Me, and 4-Me resonances of $\mathrm{LS}_{3}$ are shown. 


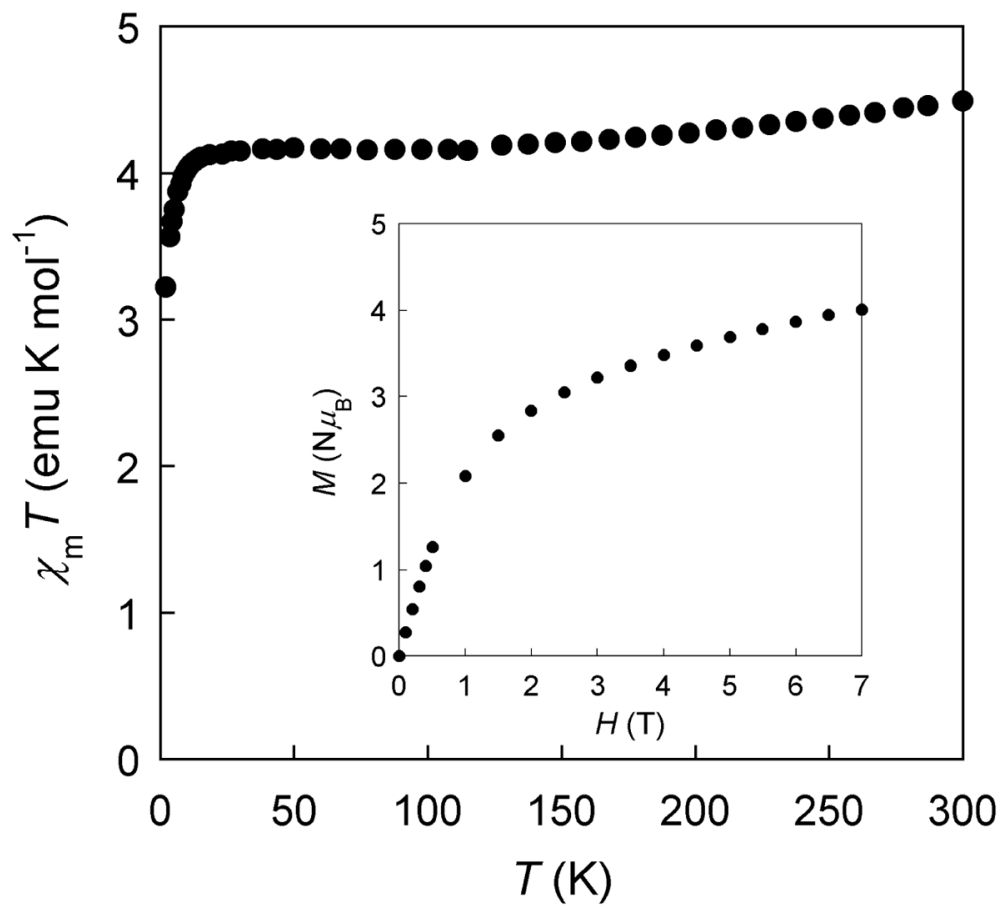

Figure 9.

Plot of $\chi_{\mathrm{m}} \mathrm{T}$ vs. $\mathrm{T}$ for polycrystalline $\left(\mathrm{Et}_{4} \mathrm{~N}\right)_{2}\left[(\mathrm{dmpe}) \mathrm{PdFe}_{3} \mathrm{~S}_{4}\left(\mathrm{LS}_{3}\right)\right]$ at $\mathrm{H}=1000 \mathrm{G}$ and $\mathrm{T}=$ 1.8-300 K. Inset: plot of magnetization vs. H showing the approach to saturation magnetization. 


\section{SUPERPOSITION OF THE CORE STRUCTURES OF $\left[(\mathrm{dmpe}) \mathrm{NiFe}_{3} \mathrm{~S}_{4}\left(\mathrm{LS}_{3}\right)\right]^{2-}$ AND C-CLUSTER OF Ch CODH (1.12 A)}

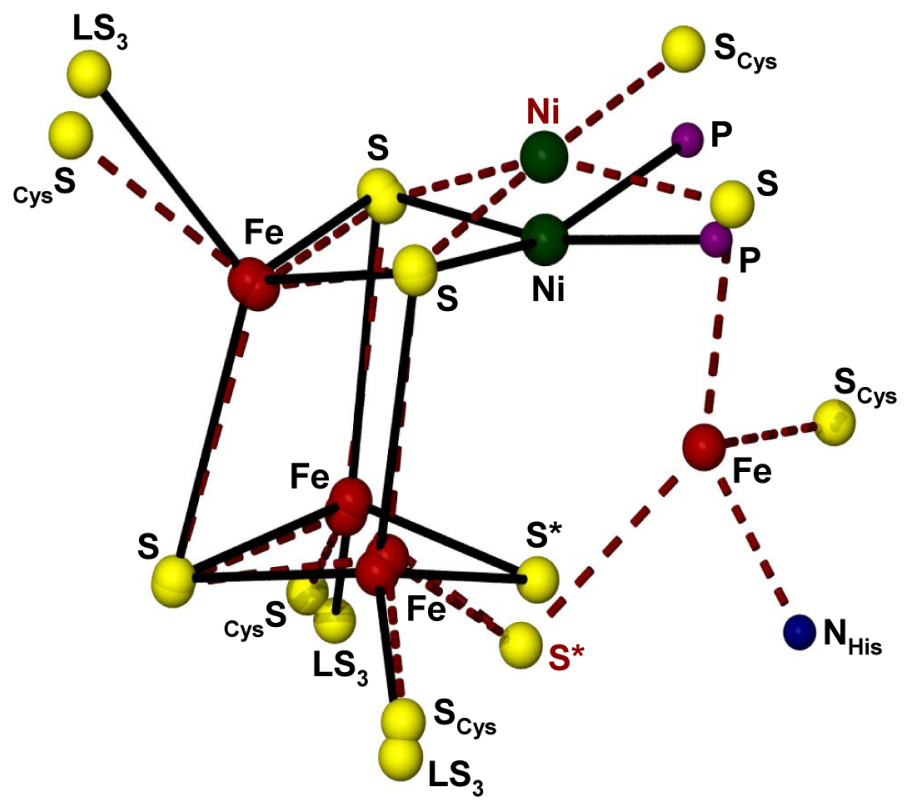

......." C-Cluster

synthetic cluster

axial $\mathrm{Ni}-\mathrm{S}^{*}$ distance in

C-cluster: $3.75 \AA$

synthetic cluster: $2.6-2.9 \AA$

Figure 10.

Superposition of the core structures of $\left[(\mathrm{dmpe}) \mathrm{NiFe}_{3} \mathrm{~S}_{4}\left(\mathrm{LS}_{3}\right)\right]^{2-}\left(\mathrm{Ni} \cdots \mathrm{S}^{*}=2.60 \AA\right)$ and $C h$ CODHII (1.12 A resolution). 


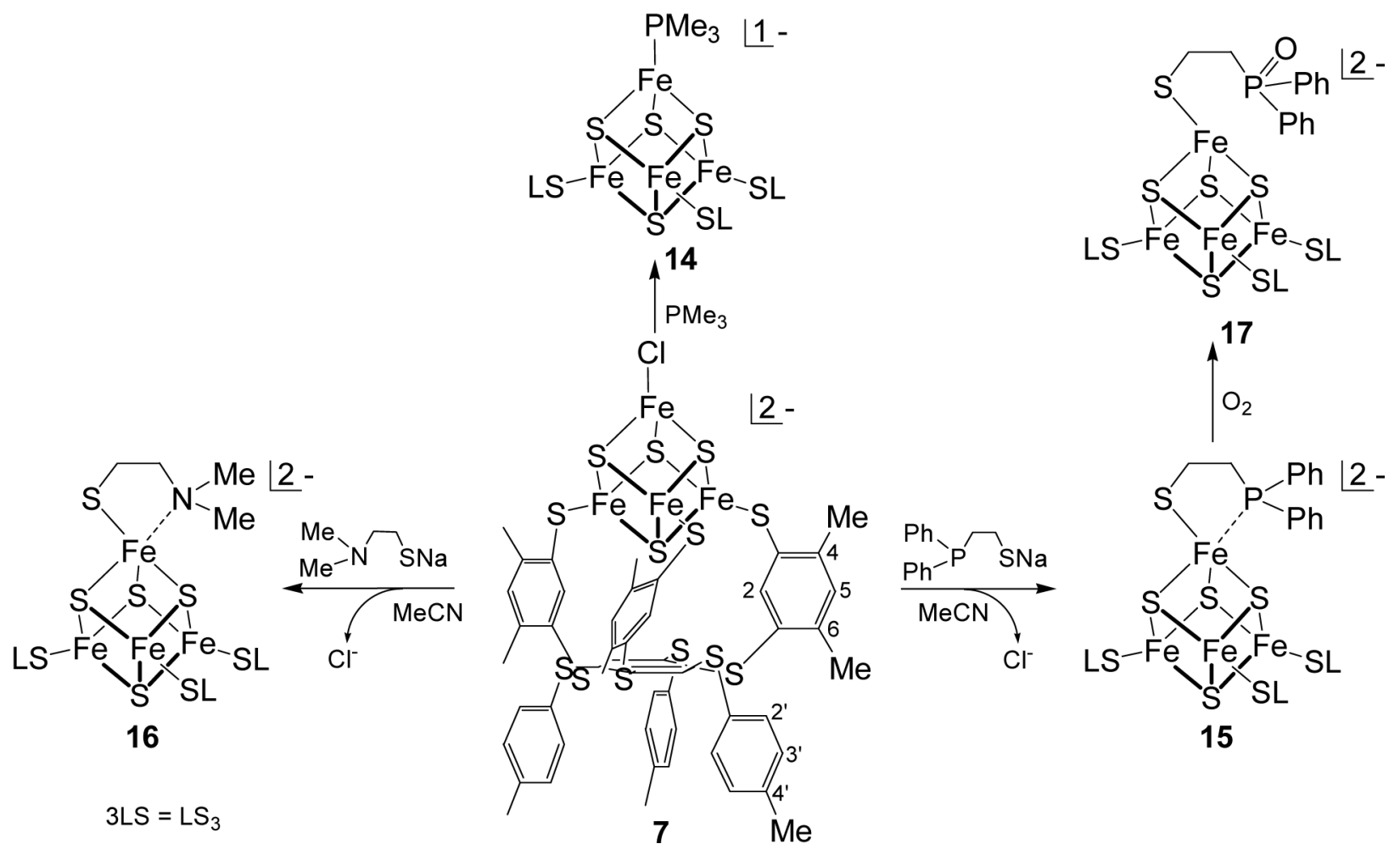

Figure 11.

Synthesis of the clusters $\left[\mathrm{Fe}_{4} \mathrm{~S}_{4}\left(\mathrm{LS}_{3}\right)\left(\mathrm{PMe}_{3}\right)\right]^{2-}(\mathbf{1 4}),\left[\mathrm{Fe}_{4} \mathrm{~S}_{4}\left(\mathrm{LS}_{3}\right)\left(\mathrm{SCH}_{2} \mathrm{CH}_{2} \mathrm{PPh}_{2}\right)\right]^{2-}(\mathbf{1 5})$, $\left[\mathrm{Fe}_{4} \mathrm{~S}_{4}\left(\mathrm{LS}_{3}\right)\left(\mathrm{SCH}_{2} \mathrm{CH}_{2} \mathrm{NMe}_{2}\right)\right]^{2-}(\mathbf{1 6})$, and $\left[\mathrm{Fe}_{4} \mathrm{~S}_{4}\left(\mathrm{LS}_{3}\right)\left(\mathrm{SCH}_{2} \mathrm{CH}_{2} \mathrm{P}(\mathrm{O}) \mathrm{Ph}_{2}\right)\right]^{2-}$, (17). 


\section{$\left[\mathrm{Fe}_{4} \mathrm{~S}_{4}\left(\mathrm{LS}_{3}\right)\left(\mathrm{SC}_{2} \mathrm{H}_{4} \mathrm{NMe}_{2}\right)\right]^{2-}$}

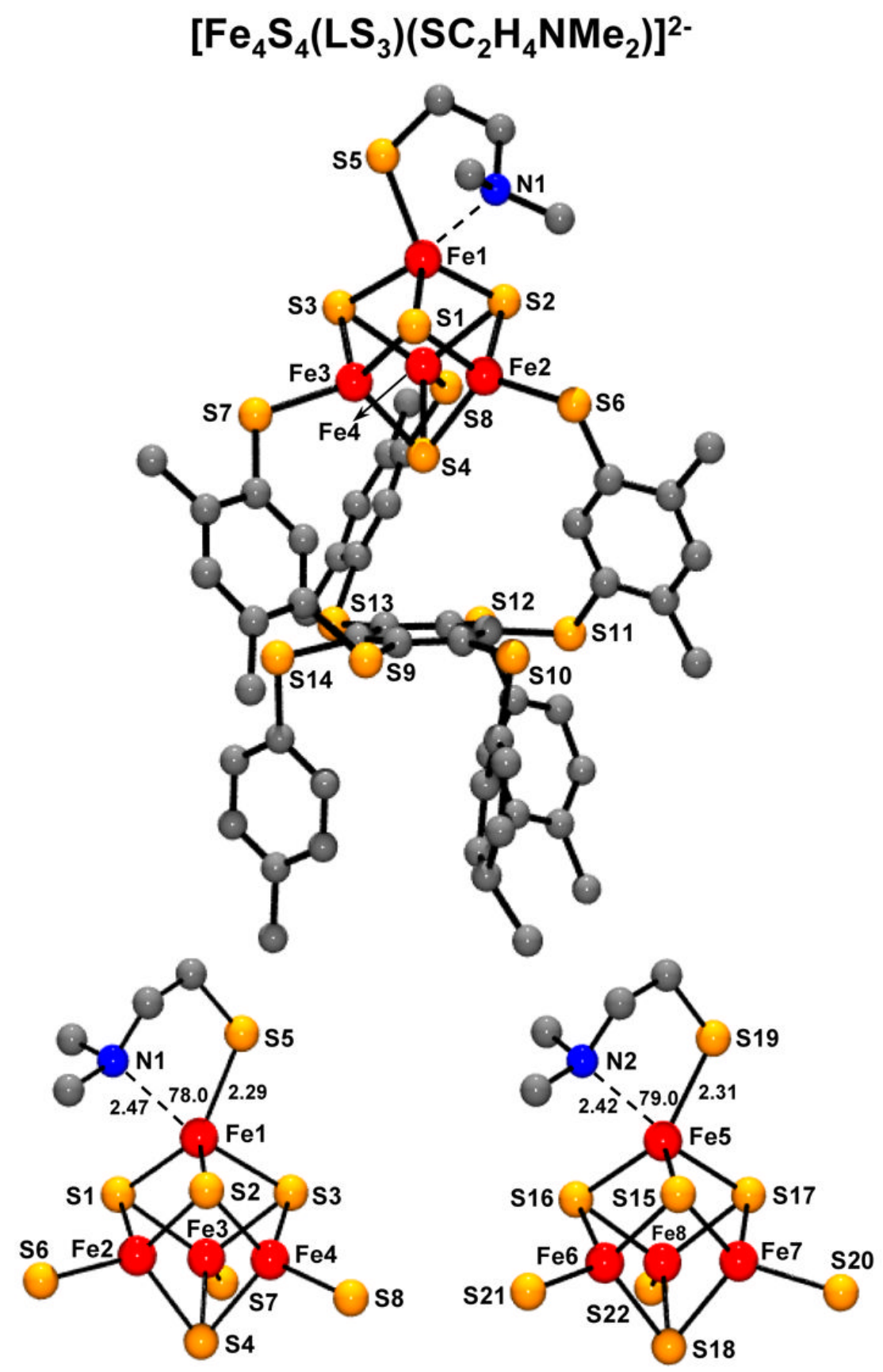

Figure 12.

Structure of one of two inequivalent clusters of $\left[\mathrm{Fe}_{4} \mathrm{~S}_{4}\left(\mathrm{LS}_{3}\right)\left(\mathrm{SCH}_{2} \mathrm{CH}_{2} \mathrm{NMe}_{2}\right)\right]^{2-}$ (upper), and structures of the $\mathrm{Fe}_{4} \mathrm{~S}_{4}$ portions of both clusters with partial atom labeling schemes and selected bond lengths $(\AA)$ and angles (deg) at the unique iron site. Both clusters have the ligand in the $a b a b a b$ conformation. 


\section{$\left[\mathrm{Fe}_{4} \mathrm{~S}_{4}\left(\mathrm{LS}_{3}\right)\left(\mathrm{SC}_{2} \mathrm{H}_{4} \mathrm{P}(\mathrm{O}) \mathrm{Ph}_{2}\right]^{2-}\right.$}

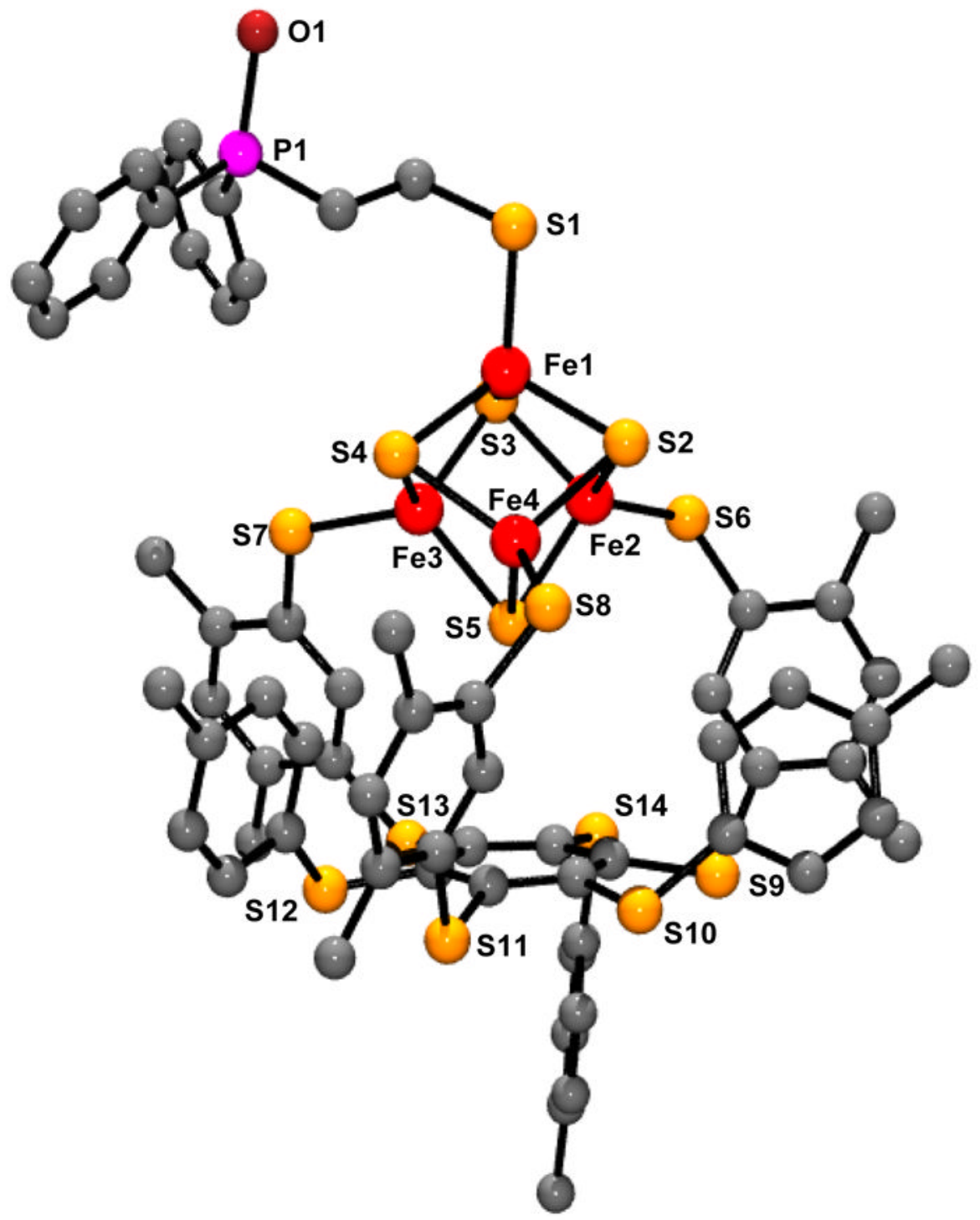

Figure 13.

Structure of $\left[\mathrm{Fe}_{4} \mathrm{~S}_{4}\left(\mathrm{LS}_{3}\right)\left(\mathrm{SCH}_{2} \mathrm{CH}_{2} \mathrm{P}(\mathrm{O}) \mathrm{Ph}_{2}\right)\right]^{2-}$ with partial atom labeling scheme; the ligand has the aaaaab conformation. 


\begin{tabular}{lc}
{$\left[\mathrm{Fe}_{3} \mathrm{~S}_{4}\left(\mathrm{LS}_{3}\right)\right]^{3-}$} & $\mathbf{1}^{25}$ \\
{$\left[\left(\mathrm{Bu}^{t} \mathrm{NC}\right) \mathrm{NiFe}_{3} \mathrm{~S}_{4}\left(\mathrm{LS}_{3}\right)\right]^{2-}$} & $\mathbf{2}$ \\
{$\left[\left(\mathrm{R}_{3} \mathrm{P}\right) \mathrm{NiFe}_{3} \mathrm{~S}_{4}\left(\mathrm{LS}_{3}\right)\right]^{2-}$} & $\mathrm{R}=\mathrm{Me} \mathbf{3}, \mathrm{Et} \mathbf{4}, \mathrm{Ph} \mathbf{5}^{17}$ \\
{$\left[(\mathrm{PhS}) \mathrm{NiFe}_{3} \mathrm{~S}_{4}\left(\mathrm{LS}_{3}\right)\right]^{3-}$} & $\mathbf{6}$ \\
{$\left[\mathrm{Fe}_{4} \mathrm{~S}_{4}\left(\mathrm{LS}_{3}\right) \mathrm{Cl}\right]^{2-}$} & $7^{24}$ \\
{$\left[\mathrm{Fe}_{4} \mathrm{~S}_{4}\left(\mathrm{LS}_{3}\right)(\mathrm{SEt})\right]^{2-}$} & $\mathbf{8}^{36}$ \\
{$\left[\left(\mathrm{dmpe}^{2-} \mathrm{NiFe}_{3} \mathrm{~S}_{4}\left(\mathrm{LS}_{3}\right)\right]^{2-}\right.$} & $\mathbf{9}^{16}$ \\
{$\left[\left(\mathrm{R}_{2} \mathrm{PCH}_{2} \mathrm{CH}_{2} \mathrm{PR}_{2}\right) \mathrm{NiFe}_{3} \mathrm{~S}_{4}\left(\mathrm{LS}_{3}\right)\right]^{2-}$} & $\mathrm{R}=\mathrm{Et} \mathbf{1 0}, \mathrm{Ph} \mathrm{11}$ \\
{$\left[\left(\mathrm{dmpe}^{2} \mathrm{PdFe}_{3} \mathrm{~S}_{4}\left(\mathrm{LS}_{3}\right)\right]^{2-}\right.$} & $\mathbf{1 2}$ \\
{$\left[\left(\mathrm{dmpe}^{2-} \mathrm{PtFe}_{3} \mathrm{~S}_{4}\left(\mathrm{LS}_{3}\right)\right]^{2-}\right.$} & $\mathbf{1 3}$ \\
{$\left[\mathrm{Fe}_{4} \mathrm{~S}_{4}\left(\mathrm{LS}_{3}\right)\left(\mathrm{PMe}_{3}\right)\right]^{1-}$} & $\mathbf{1 4}$ \\
{$\left[\mathrm{Fe}_{4} \mathrm{~S}_{4}\left(\mathrm{LS}_{3}\right)\left(\mathrm{SCH}_{2} \mathrm{CH}_{2} \mathrm{PPh}_{2}\right)\right]^{2-}$} & $\mathbf{1 5}$ \\
{$\left[\mathrm{Fe}_{4} \mathrm{~S}_{4}\left(\mathrm{LS}_{3}\right)\left(\mathrm{SCH}_{2} \mathrm{CH}_{2} \mathrm{NMe}_{2}\right)\right]^{2-}$} & $\mathbf{1 6}$ \\
{$\left[\mathrm{Fe}_{4} \mathrm{~S}_{4}\left(\mathrm{LS}_{3}\right)\left(\mathrm{SCH}_{2} \mathrm{CH}_{2} \mathrm{P}(\mathrm{O}) \mathrm{Ph}_{2}\right)\right]^{2-}$} & $\mathbf{1 7}$ \\
\hline
\end{tabular}

bdt = benzene-1,2-dithiolate(2-), Ch, Carboxydothermus hydrogenoformans; CODH; cod, 1,5cyclooctadiene, dba, dibenzylideneacetone, $\mathrm{CODH}$, carbon monoxide dehydrogenase; dmpe = bis(1,2-dimethylphosphino)ethane, edt = ethane-1,2-dithiolate(2-), $\mathrm{LS}_{3}=1,3,5$-tris((4,6-dimethyl3-mercaptophenyl)thio)-2,4,6-tris( $p$-tolylthio)benzene(3-), 3LS $=\mathrm{LS}_{3}$; mes = mesityl; mnt = maleonitriledithiolate(2-), Mt, Moorella thermoacetica; $\mathrm{ndt}=$ bicyclo[2.2.1]hepta-exo-cis-2,3dithiolate(2-); $R r$, Rhodospirillum rubrum

Chart.

Designation of Clusters and Abbreviations 


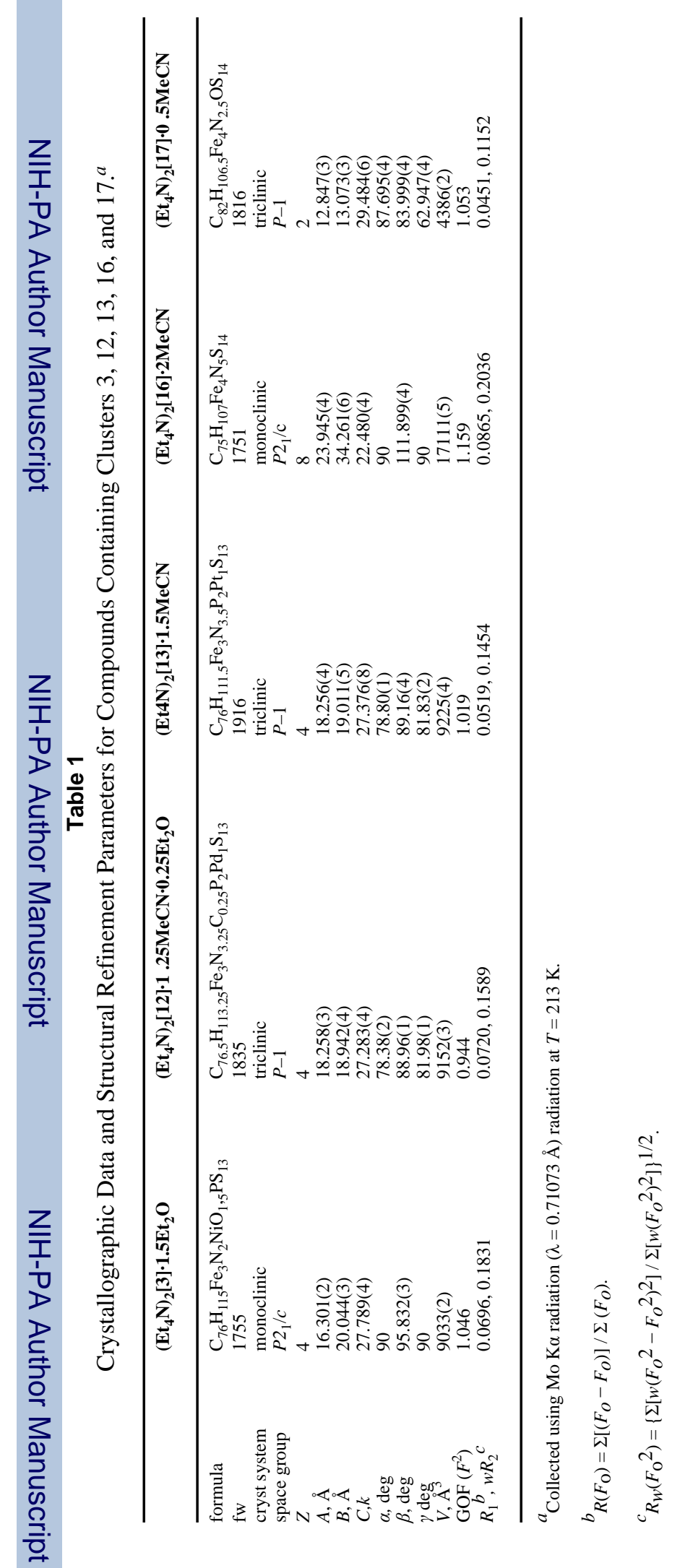




\section{Table 2}

Selected Interatomic Distances $(\AA)$ and Angles (deg) for the Heterometal Clusters $\left[\left(\mathrm{Me}_{3} \mathrm{P}\right) \mathrm{NiFe}_{3} \mathrm{~S}_{4}\left(\mathrm{LS}_{3}\right)\right]^{2-}(\mathbf{3})$ and $\left[(\mathrm{dmpe}) \mathrm{MFe}_{3} \mathrm{~S}_{4}\left(\mathrm{LS}_{3}\right)\right]^{2-}, \mathrm{M}=\mathrm{Pd}(\mathbf{1 2})$ and $\mathrm{Pt}(\mathbf{1 3})$

\begin{tabular}{|c|c|c|c|}
\hline & $3^{a}$ & $12^{b}$ & ${ }_{13}^{c}$ \\
\hline M-P1 & $2.204(3)$ & $2.235(4)$ & $2.219(2)$ \\
\hline M-P2 & -- & $2.240(5)$ & $2.230(2)$ \\
\hline M-S1 & $2.260(3)$ & $2.435(4)$ & $2.439(2)$ \\
\hline M-S2 & $2.270(2)$ & $3.017(4)$ & $3.107(3)$ \\
\hline M-S3 & $2.260(2)$ & $2.398(4)$ & $2.394(2)$ \\
\hline Fe1-S1 & $2.291(2)$ & $2.319(4)$ & $2.307(2)$ \\
\hline $\mathrm{Fe} 1-\mathrm{S} 2$ & $2.288(2)$ & -- & -- \\
\hline Fe1-S3 & -- & $2.278(4)$ & $2.279(2)$ \\
\hline $\mathrm{Fe} 1-\mathrm{S} 4$ & $2.269(2)$ & $2.304(4)$ & $2.295(1)$ \\
\hline $\mathrm{Fe} 2-\mathrm{S} 1$ & $2.266(2)$ & $2.359(4)$ & $2.359(2)$ \\
\hline $\mathrm{Fe} 2-\mathrm{S} 2$ & -- & $2.224(5)$ & $2.233(2)$ \\
\hline $\mathrm{Fe} 2-\mathrm{S} 3$ & $2.290(3)$ & -- & -- \\
\hline $\mathrm{Fe} 2-\mathrm{S} 4$ & $2.312(2)$ & $2.335(5)$ & $2.328(2)$ \\
\hline $\mathrm{Fe} 3-\mathrm{S} 2$ & $2.281(2)$ & $2.267(5)$ & $2.251(2)$ \\
\hline $\mathrm{Fe} 3-\mathrm{S} 3$ & $2.291(3)$ & $2.379(4)$ & $2.387(2)$ \\
\hline $\mathrm{Fe} 3-\mathrm{S} 4$ & $2.306(2)$ & $2.301(4)$ & $2.309(2)$ \\
\hline $\mathrm{Fe}-\mathrm{SL}^{d}$ & $2.303(7)$ & $2.332(8)$ & $2.32(2)$ \\
\hline S4-ctr ${ }^{e}$ & $3.79(2)$ & $3.752(4)$ & $3.741(4)$ \\
\hline P1-M-P2 & -- & $86.3(2)$ & $87.00(6)$ \\
\hline P1-M-S1 & $118.4(1)$ & $89.7(2)$ & $89.81(5)$ \\
\hline P1-M-S2 & $115.7(1)$ & -- & -- \\
\hline P1-M-S3 & $104.7(1)$ & $171.9(2)$ & $174.43(5)$ \\
\hline P2-M-S3 & -- & $86.8(2)$ & $88.00(5)$ \\
\hline S1-M-S3 & $106.03(9)$ & $97.2(1)$ & $95.25(5)$ \\
\hline S1-M-S2 & $105.52(9)$ & -- & -- \\
\hline S2-M-S3 & $105.41(9)$ & -- & -- \\
\hline $\mathrm{Fe} 2-\mathrm{S} 2-\mathrm{Fe} 3$ & -- & $73.6(1)$ & 73.94(5) \\
\hline $\mathrm{MS} 1 \mathrm{~S} 3 / \mathrm{Fe} 2 \mathrm{~S} 2 \mathrm{Fe} 3^{f}$ & $(\alpha)--$ & $23.0(3)$ & $25.85(9)$ \\
\hline $\mathrm{Fe} 2 \mathrm{~S} 4 \mathrm{Fe} 3 / \mathrm{Fe} 2 \mathrm{~S} 2 \mathrm{Fe} 3{ }^{f}$ & ( $\beta)--$ & $24.2(3)$ & $25.10(9)$ \\
\hline
\end{tabular}

${ }^{a} \mathrm{M}=\mathrm{Ni}$ II

${ }^{b} \mathrm{M}=\mathrm{Pd}$ II; one of two independent clusters

${ }^{c} \mathrm{M}=\mathrm{Pt}{ }^{\mathrm{II}}$; one of two independent clusters.

${ }^{d}$ Mean value of terminal bond lengths.

${ }^{e}$ Distance from S4 to the centroid of the central benzene ring.

$f_{\text {Dihedral angle. }}$ 


\section{Table 3}

Mössbauer and Redox Properties of $\left[(\mathrm{dmpe}) \mathrm{MFe}_{3} \mathrm{~S}_{4}\left(\mathrm{LS}_{3}\right)\right]^{2-}(\mathrm{M}=\mathrm{Ni}, \mathrm{Pd}, \mathrm{Pt})$

\begin{tabular}{|c|c|c|c|c|}
\hline $\mathbf{M}$ & $\delta(\mathbf{m m} / \mathbf{s})^{b}$ & $\Delta \mathrm{E}_{\mathbf{Q}}(\mathrm{mm} / \mathbf{s})^{b}$ & \multicolumn{2}{|c|}{$\begin{array}{c}E_{1 / 2}(\mathrm{~V})^{a} \\
{\left[\mathrm{MFe}_{3} \mathrm{~S}_{4}\right]^{0} \leftrightarrow\left[\mathrm{MFe}_{3} \mathrm{~S}_{4}\right]^{1+} \leftrightarrow\left[\mathrm{MFe}_{3} \mathrm{~S}_{4}\right]^{2+}}\end{array}$} \\
\hline $\mathrm{Ni}^{c}$ & $\begin{array}{r}0.64 \\
\sim 0.54\end{array}$ & $\begin{array}{l}2.72 \\
\text { variable }\end{array}$ & $-1.03^{d}$ & $-0.01^{e}$ \\
\hline $\mathrm{Pd}$ & $\begin{array}{l}0.63 \\
0.51\end{array}$ & $\begin{array}{l}2.54(1)^{h} \\
1.11(3)\end{array}$ & $-1.02^{f}$ & $+0.19^{e}$ \\
\hline $\mathrm{Pt}$ & $\begin{array}{l}0.63 \\
0.51\end{array}$ & $\begin{array}{l}2.45(1) \\
1.16(3)\end{array}$ & $-1.02^{f}$ & $+0.11^{e}$ \\
\hline
\end{tabular}

$a_{\text {vs. SCE. }}$

$b_{77 \mathrm{~K} .}$

${ }^{c}$ Ref. 16.

$d_{\text {Acetonitrile }}$

${ }^{e} E_{\mathrm{pa}}$ for irreversible process.

$f_{\text {DMF. }}$

${ }^{g}$ Complex spectrum.

$h_{\text {Relative intensities. }}$ 
Table 4

Selected Interatomic Distances (A) and Angles (deg) for Site-Differentiated $\mathrm{Fe}_{4} \mathrm{~S}_{4}$ Clusters $\left[\mathrm{Fe}_{4} \mathrm{~S}_{4}\left(\mathrm{LS}_{3}\right)\right.$ $\left.\left(\mathrm{SCH}_{2} \mathrm{CH}_{2} \mathrm{Nme}_{2}\right)\right]^{2-}(\mathbf{1 6})$ and $\left[\mathrm{Fe}_{4} \mathrm{~S}_{4}\left(\mathrm{LS}_{3}\right)\left(\mathrm{SCH}_{2} \mathrm{CH}_{2} \mathrm{P}(\mathrm{O}) \mathrm{Ph}_{2}\right]^{2-}(\mathbf{1 7})\right.$

\begin{tabular}{|c|c|c|c|}
\hline & $16^{a}$ & & 17 \\
\hline $\mathrm{Fe} 1-\mathrm{S} 5 / \mathrm{S} 1^{b}$ & $2.294(3)$ & & $2.248(1)$ \\
\hline Fe1-N1 & $2.47(1)$ & & -- \\
\hline $\mathrm{Fe} 1-\mathrm{S} 1 / \mathrm{S} 2$ & $2.323(3)$ & & $2.255(1)$ \\
\hline $\mathrm{Fe} 1-\mathrm{S} 2 / \mathrm{S} 4$ & $2.278(3)$ & & $2.309(1)$ \\
\hline $\mathrm{Fe} 1-\mathrm{S} 3$ & $2.437(3)$ & & $2.284(1)$ \\
\hline $\mathrm{Fe} 2-\mathrm{S} 1 / \mathrm{S} 3$ & $2.259(3)$ & & $2.276(1)$ \\
\hline $\mathrm{Fe} 2-\mathrm{S} 2$ & $2.311(3)$ & & $2.281(1)$ \\
\hline $\mathrm{Fe} 2-\mathrm{S} 4 / \mathrm{S} 5$ & $2.299(3)$ & & $2.303(1)$ \\
\hline $\mathrm{Fe} 3-\mathrm{S} 1 / \mathrm{S} 5$ & $2.293(3)$ & & $2.273(1)$ \\
\hline Fe3-S3 & $2.274(3)$ & & $2.315(1)$ \\
\hline Fe3-S4 & $2.254(3)$ & & $2.277(1)$ \\
\hline Fe4-S2 & $2.294(3)$ & & $2.297(1)$ \\
\hline Fe4-S3/S4 & $2.249(3)$ & & $2.267(1)$ \\
\hline $\mathrm{Fe} 4-\mathrm{S} 4 / \mathrm{S} 5$ & $2.295(3)$ & & $2.281(1)$ \\
\hline $\mathrm{Fe}-\mathrm{SL}^{c}$ & $2.279(1)$ & & $2.257(6)$ \\
\hline $\mathrm{S} 4 / \mathrm{S} 5-\mathrm{ctr}^{d}$ & $3.673(5)$ & & $3.736(2)$ \\
\hline S1-Fe1-S5 & $128.4(1)$ & $\mathrm{S} 2-\mathrm{Fe} 1-\mathrm{S} 1$ & $108.90(5)$ \\
\hline S2-Fe1-S5 & $123.8(1)$ & S3-Fe1-S1 & $117.41(4)$ \\
\hline S3-Fe1-S5 & $90.9(1)$ & S4-Fe1-S1 & $116.24(5)$ \\
\hline S2-Fe1-S3 & $97.5(1)$ & S4-Fe1-S2 & $104.72(2)$ \\
\hline S3-Fe1-N1 & $168.5(3)$ & & -- \\
\hline S1-Fe1-S2 & 105.4(1) & & -- \\
\hline S1-Fe1-S3 & $98.2(1)$ & & -- \\
\hline
\end{tabular}

${ }_{\mathrm{Et} 4 \mathrm{~N}^{+}}$salt; one of two inequivalent clusters.

${ }^{b}$ Atom labels in order 16/17.

${ }^{c}$ Mean value of terminal bond lengths.

${ }^{d}$ Distance from S4/S5 to the centroid of the central benzene ring. 